\title{
The Impact of Extended Heat Exposure on Rapid Sulphoaluminate Cement Concrete Up To $120^{\circ} \mathrm{C}$
}

\author{
Jean Jacques Kouadjo Tchekwagep ${ }^{1}$, Anol K. Mukhopadhyay ${ }^{2}$, Shoude Wang ${ }^{1}$, Shifeng Huang ${ }^{1 *}$, \\ Xin Cheng ${ }^{1}$

\footnotetext{
${ }^{1}$ School of Materials Science and Engineering, University of Jinan, Jinan, Shandong, P.O.B. 250022, China

${ }^{2}$ Shandong Provincial Key Laboratory of Preparation and Measurement of Building Materials, Jinan, Shandong 250022, China

* Corresponding author, e-mail: mse_huangsf@ujn.edu.cn
}

Received: 31 August 2020, Accepted: 28 January 2021, Published online: 08 February 2021

\begin{abstract}
This study examined the stability of rapid sulphoaluminate cement concrete (R-SACC) when exposed to heat for extended periods of time. The physicochemical processes present in R-SACC as a function of temperature were determined through various tests. The general behavior of rapid sulphoaluminate cement (R-SAC) at a range of temperatures is summarized. The results show that observing color change could be a simple way to identify deterioration of R-SACC, along with the rebound hammer. The matrix formation of ettringite was broken and the mass of the hydrated product decreased with heat exposure; the major mineral composition of the paste consisted of $\mathrm{CaSO} 4, \mathrm{CaCO} 3$ and $\beta$ - $\mathrm{C} 2 \mathrm{~S}$; and the interface between aggregate and paste in the R-SACC become loosely structured with cracks. Between $50^{\circ} \mathrm{C}$ and $120^{\circ} \mathrm{C}$, the rapid sulphoaluminate cement (R-SAC) paste first expanded and then shrank, and the shrinkage rate of R-SAC was much greater than that of R-SACC.
\end{abstract}

Keywords

R-SAC concrete, thermal damage, R-SAC cement paste, thermal resistance, stress-strain

\section{Introduction}

Rapid sulphoaluminate cement concrete (R-SACC) is widely used as an important structural material. China and other countries, such as India, have used billions of tons of R-SACC in construction due to its several advantages, such as high early strength, short setting time, good corrosion, freeze-thaw resistance, and low production cost, which give it the prospect of reaching a broad market. Concrete structural members, when used in construction, must meet fire safety specification specified in construction codes [1,2]. This is because fire represents one of the most severe environmental threats to which R-SACC may be subjected. Therefore, the planning of appropriate fire safety measures for structural components is a foremost aspect of ensuring building stability. Numerous issues related to R-SACC structures are becoming important factors in many industries. These include the risk of structural collapse when heated to a certain extent, property deterioration caused by aggressive environmental impacts, and premature strength. By 2050, the use of concrete overall is forecasted to reach four times the amount in 1990 [3]. Therefore, rapid sulphoaluminate cement
(R-SAC) is getting increased attention since its manufacture produces less $\mathrm{CO}_{2}$ than that of Portland cement [4]. This cement may have quite changeable composition, but all forms of it have a Ye'elimite phase, also called tetracalcium trialuminate sulfate (C4A3S), as the main phase [5]. It may also have a minor phase such as $\mathrm{C}_{2} \mathrm{~S}, \mathrm{CA}, \mathrm{C}_{4} \mathrm{AF}$, $\mathrm{CS}, \mathrm{C}_{\mathrm{S}} \mathrm{H}_{2}$ [6], where $\mathrm{C}$ is used to represent $\mathrm{CaO}, \mathrm{S}$ represents $\mathrm{SiO}_{2}$, A represents $\mathrm{Al}_{2} \mathrm{O}_{3}, \mathrm{~F}$ represents $\mathrm{Fe}_{2} \mathrm{O}_{3}, \mathrm{~S}$ represents $\mathrm{SO}_{3}, \mathrm{M}$ represents $\mathrm{MgO}$, T represents $\mathrm{TiO}_{2}$ and $\mathrm{H}$ represents $\mathrm{H}_{2} \mathrm{O}$. The paste and concretes obtained from this cement show high early strength development [7] and could also be utilized for radioactive component encapsulation [8]. Ettringite is one of the most important elements giving early strength to R-SAC, it constitutes one of the principal components of the structural matrix formed by hardened R-SAC. Caporale et al. [9] and Zhou [10] has shown that its dehydration at $50^{\circ} \mathrm{C}$ to $65^{\circ} \mathrm{C}$ entails a rapid loss of water; this temperature range represents the zone of ettringite persistence. The post-decomposition at $95^{\circ} \mathrm{C}$ registers more loss of water by the AFt followed by a complete decomposition at $120^{\circ} \mathrm{C}$. Its decomposition is 
a mixture of gypsum and amorphous material as a dehydrated product.Hence, the temperature range at which we can study our sample is $50^{\circ} \mathrm{C}$ to $120^{\circ} \mathrm{C}$.

R-SACC is frequently used to build power plants in China and India that could possibly put millions of people in danger, so it is essential for engineers to find ways to rapidly monitor the extent of deterioration in existing buildings. Therefore, it is important to address the potential negative effect that dehydration at this range of temperatures could have on the cement's strength. In the best-known papers describing the effect of heat damage on the properties of cements, concretes, and aggregates generally [11, 12], no mention is made of changes in other important physical and mechanical characteristics of concretes and their components as a result of exposure to the surrounding heat. When a building structure experiences elevated temperatures for an extended period of time, concrete is prone to cracking. The high density of the R-SAC and the aggregate thermal expansion coefficient could be important factors affecting the structures. They are bound to increase the thermal stress inside the heated structure, making it more crackable. When cracks occur in concrete, its thermal resistance is significantly reduced. Studies by Damidot and Glasser [13], Sanfelix et al. [14] and Collier [15] pointed out that when a $0.4 \mathrm{~cm}$ crack occurs in a $20 \mathrm{~cm}$-thick concrete structure, its thermal protection performance drops to less than $10 \%$ of the original. Therefore, concrete should have good thermal stability to ensure its load-bearing ability. The temperature at some structures, such as power plants, under normal operating conditions can be as high as $120^{\circ} \mathrm{C}$ [16-19]. The objective of this limited study was to provide data and information on the effects of elevated temperatures between $50^{\circ}$ and $120^{\circ} \mathrm{C}$ on the mechanical behavior of the R-SAC-based materials for use in assessments of power plant concrete structures that are subjected to temperatures in excess of the current Chinese Society of Mechanical Engineers Code limitations. In this study, the compressive, flexural and tensile strength of R-SACC after exposure to temperatures of $50^{\circ}$ to $120^{\circ} \mathrm{C}$ was tested. In addition, we have proposed and texted two methods for quick identification thermally induced deterioration in R-SACC, particularly the rebound hammer and colorimeter. Finally, the thermal decomposition, and microstructure were studied by using an X-ray diffraction instrument and SEM/EDS tools.

\subsection{Experimental program}

The experiments aimed to determine the change of strength of R-SACC in the zone of ettringite persistence, where the ettringite matrix remains in high concentration even though there is ongoing dehydration, and in the zone of ettringite decomposition, where the loss of water by the AFt is more obvious at temperatures up to $120^{\circ} \mathrm{C}$, as illustrated in Fig. 1. The specific exposure temperatures were chosen based on expected critical chemical and micro-structural behavior changes and to represent the range of low-temperature exposures common to buildings.

\subsubsection{Significance of the study}

Results from this study can complement previous research in helping to predict the degree of decay that a structure or structural element made with R-SAC could face. This aspect is of great importance for designing the reconstruction, reinforcement or retrofitting of such a structure or structural element. Gaining a more precise understanding of the failure mechanisms of R-SACC could help us increase fire resistance in buildings in which it is used.

\subsubsection{Heat}

In large concrete masses, such as dams, and in other facilities, heat dissipates very slowly, so the whole structure experiences a rise in temperature. This rise in turn causes volume expansion of the concrete. Eventually, the temperature rise reaches a maximum and then the structure begins to cool slowly. With subsequent cooling, the material begins to contract. As the material heats and cools repeatedly, it expands and contracts, and cracking can result.

\section{Mix proportions and materials}

The concrete grade $\mathrm{C} 40$ was adopted in this work, corresponding to a nominal strength of $72.1 \mathrm{MPa}$. For the experimental R-SACC mix, the fine aggregate was medium sand from the Yangtze River, with a fineness modulus of 2.5 and apparent density of $2584 \mathrm{~kg} / \mathrm{m}^{3}$. The coarse aggregate was

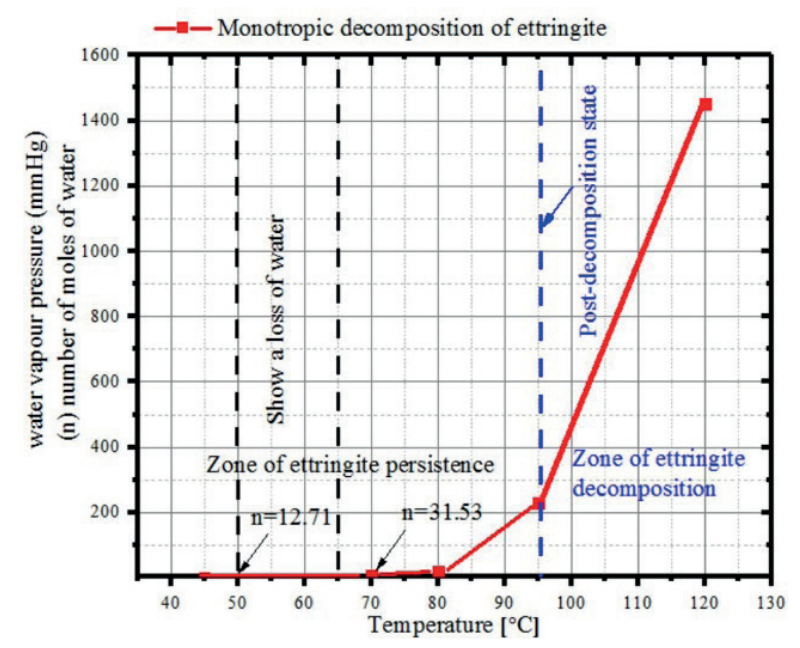

Fig. 1 Monotropic decomposition of ettrinigite 
between 4-25 mm granite crushed stone, with an apparent density of $2643 \mathrm{~kg} / \mathrm{m}^{3}$ (Table 1). R-SAC P.O 42.5 grade cement (Table 2) from Wuhan Yadong Yangfang Cement Group Co., Ltd. was used. It has a specific surface area of $348 \mathrm{~m}^{2} / \mathrm{kg}$ with a water absorption rate of $0.83 \%$. The proportions of concrete are given in Table 3. Preliminary tests (specific gravity, sieve analysis) were performed on the aggregates (river sand and crushed granite) in accordance with Bs 812 , and workability tests were performed on the fresh concrete to determine their suitability.

\subsection{Sample preparation}

R-SACC mixing took place with the aid of a mixer; the concrete was prepared according to the mixing ratio shown in Table 3. A sample size of $40 \times 40 \times 150 \mathrm{~mm}(15 \mathrm{sam}-$ ples) was adopted for tests of the flexural strength, tensile strength, mass changes, ultrasonic waves, and shrinkage; then a sample size of $100 \times 100 \times 100 \mathrm{~mm}(15$ samples $)$ was

Table 1 Aggregate gradation

\begin{tabular}{cccc}
\hline \multicolumn{2}{c}{ Limestone $[4-25] \mathrm{mm}$} & \multicolumn{2}{c}{ Quartz sand [0.4-4.75] mm } \\
Sieve size $[\mathrm{mm}]$ & \% Passing & Sieve size $[\mathrm{mm}]$ & \% Passing \\
\hline $20-25$ & 100 & $2.36-4.75$ & 100 \\
$15-20$ & 50 & $1.18-2.36$ & 45 \\
$10-15$ & 25 & $0.6-1.18$ & 25 \\
$5-10$ & 155 & $0-0.4$ & 20 \\
$0-4$ & 5 & - & - \\
\hline
\end{tabular}

Table 2 Chemical composition of cement R-SAC-42.5

\begin{tabular}{lc}
\hline Component of cement & \% of total \\
\hline $\mathrm{CaO}$ & 45.28 \\
$\mathrm{Al}_{2} \mathrm{O}_{3}$ & 17.51 \\
$\mathrm{SO}_{3}$ & 15.76 \\
$\mathrm{SiO}_{2}$ & 9.19 \\
$\mathrm{Fe}_{2} \mathrm{O}_{3}$ & 2.50 \\
$\mathrm{MgO}$ & 1.90 \\
$\mathrm{TiO}_{2}$ & 0.75 \\
$\mathrm{~K}_{2} \mathrm{O}$ & 0.48 \\
$\mathrm{Na}_{2} \mathrm{O}$ & 0.48 \\
\hline
\end{tabular}

Table 3 Composition of individual mix designs

\begin{tabular}{lcc}
\hline Component & Concrete Mix weight $(\mathrm{kg})$ & Paste Mix weight $(\mathrm{kg})$ \\
\hline R-SAC 42.5R & 540 & 300 \\
Sand (quartz) & 622 & - \\
$\begin{array}{l}\text { Coarse aggregate } \\
\text { (basalt) }\end{array}$ & 727 & - \\
Water & 216 & 120 \\
w/c ratio & 0.4 & 0.4 \\
\hline
\end{tabular}

used to perform the rebound hammer number non-destructive test, along with tests of compressive strength, stressstrain, mass loss and Poisson ratio for each temperature. In addition, $20 \mathrm{~mm}$ cubic specimens (15 samples) were produced to represent R-SAC paste so as to understand the dehydration phase that occurs as temperature increases.

\subsection{Curing process}

Immediately after the samples had been cast and consolidated, they were placed in a concrete chamber of the material testing cure room with a temperature range of $+20^{\circ} \mathrm{C} \pm 1.5^{\circ} \mathrm{C}$ for $24 \mathrm{~h}$; after that, they were demolded and stored in a curing chamber at a constant temperature of $20^{\circ} \mathrm{C}$ and a relative humidity of $95 \%$ for 28 days. Then they were air-dried inside the laboratory for 7 days.

\subsubsection{Testing procedure}

Prior to any other testing, the width of the cracks in each sample was measured using an intelligent crack width meter [20], the experimental device shown in Fig. 2(c). When the probe was aimed at the crack during the test, the magnified crack image could be seen on the LCD screen. A fine-tune probe made the image clearer and saved it. Then the color images of each sample surface were analyzed, using a method in accordance with recent studies that evaluated the color change in heated concrete [21-24]. Pictures were taken with a stereomicroscope, with a flatbed at the same scale. The images were then analyzed using the ImageJ analysis software package called Scion Image (version 4.0.3, Scion Corporation ${ }^{\circ}$, USA) [25]. This package enabled us to measure the intensity of various component colors in regions of interest (ROIs). After that, the ultrasonic test was conducted; changes in ultrasonic waves can reflect the internal degradation of the concrete structure and predict internal collapse [26-29]. A Tektronix AFG3022B arbitrary waveform generator and Tektronix TDS1002B-SC provided the source and receiver signals, respectively, as digital oscilloscope in this experiment (Fig. 3). The ultrasonic frequency was $30 \mathrm{kHz}$ and the input voltage was $10 \mathrm{~V}$. The transmitting amplitude values and waveform of the ultrasonic waves were recorded. The experimental device is shown in Fig. 2(d). For the ultrasonic test, grease was applied as couplant to enhance adequate contact between the R-SACC and the transducers.

Next, the rebound hammer test was conducted; the surface samples under investigation were systematically smoothed in all cases. During this test, the plunger of the rebound hammer is pressed against the surface of the 


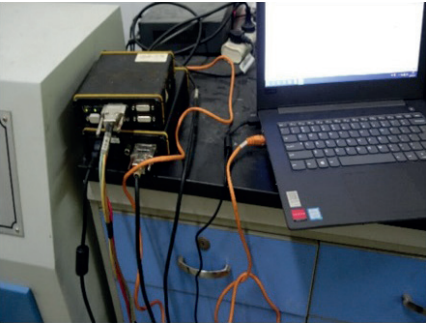

(a)

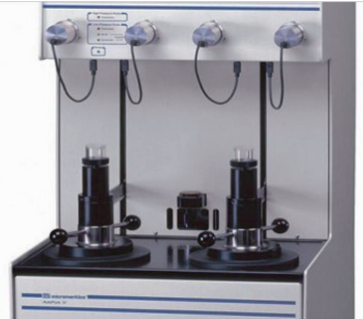

(b)

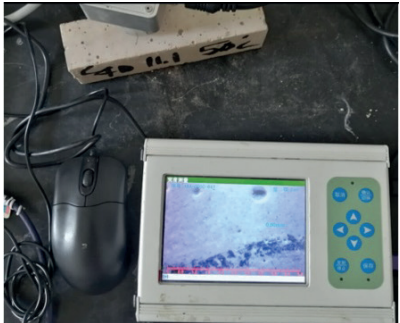

(c)

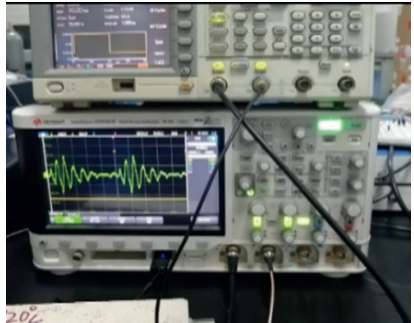

(d)

Fig. 2 Main experimental device a) static strain collector instument model: DH3821, b) Mike autu pore 9605, c) crack width meter, d) ultrasonic test device

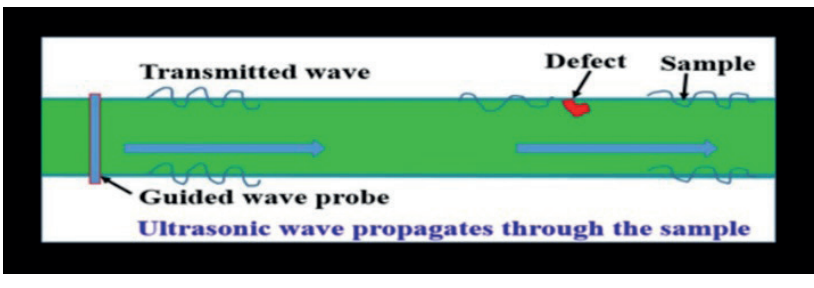

Fig. 3 Ultrasonic test schematic diagram

R-SACC after being exposed to the target temperature. A spring-controlled mass with constant energy is made to hit the concrete surface; when it rebounds back, the force of the rebound, which is a measure of surface hardness, is measured on a graduated scale. This study included two non-destructive test (NDT) methods that enable certain properties of the R-SACC to be evaluated in situ, from which an estimation of the quality of the concrete was made. Before exposure, the samples of $40 \times 40 \times 150$, $100 \times 100 \times 100$ and $20 \times 20 \times 20 \mathrm{~mm}$ were weighed $\left(M_{0}\right)$. Some samples were then reserved and used as controls $\left(20^{\circ} \mathrm{C}\right)$. Then the other samples were subjected to varying temperatures from $50^{\circ}$ to $120^{\circ} \mathrm{C}$. Previous studies by Tchekwagep et al. [30] have shown that major physico-chemical changes occur between $20^{\circ}$ and $120^{\circ} \mathrm{C}$, so we selected picked roughly equal increments to cover the range. The temperatures of $20^{\circ}$ and $100^{\circ} \mathrm{C}$ were chosen to match previous studies as "control points"; $50^{\circ}$ and $70^{\circ} \mathrm{C}$ were chosen as intermediate temperatures within the zone of ettringite persistence. Each temperature was maintained for 4 hours, to attain steady state conditions (thermal equilibrium) [31] in the specimens at all target temperatures. The temperature was increased at a rate of $4^{\circ} \mathrm{C} / \mathrm{min}$ inside the electric furnace. After the 4-hr period, the samples were immediately weighed and the distance from the surface was measured (for both the concrete samples and cement samples), then they were left to cool down in the furnace at a rate of $2^{\circ} \mathrm{C} / \mathrm{min}$ to ambient temperature $\left(20^{\circ} \mathrm{C}\right)$ and weighed $\left(M_{i}\right)$ with an electronic balance of $0.01 \mathrm{~g}$ precision. The control and exposed samples were then tested for strength performance using appropriate machines for each test. Loads were applied to the R-SACC at the rate of $0.5 \mathrm{MPa} / \mathrm{s}, 0.05 \mathrm{MPa} / \mathrm{s}$ and $0.01 \mathrm{MPa} / \mathrm{s}$ for the compressive strength, flexural strength and tensile strength tests, respectively, according to the Chinese standard. Each sample of $100 \times 100 \times 100 \mathrm{~mm}$ was equipped on the surface with four strain gauge sensors, two installed vertically and two horizontally (BQ120-80AA-P200) on the surface of each sample, able to record the change in stress-strain in the R-SACC. Before we performed the compressive stressstrain test, moisture in each sample was determined with an electronic meter. Tests were performed and the separate strain deformations were recorded through a linear transformer (DH3821 static strain collector [32, 33] (see Fig. 2(a)) to quantify our understanding of the stress-strain relationship and Poisson ratio of the R-SACC after exposure to different elevated temperatures. The residual strength of the sample is the ratio of the strength at temperature $\Theta^{\circ} \mathrm{C}$ to that at ambient temperature. A graph of compressive, flexural, tensile and residual strength $(R s)$ versus temperature was plotted to study the failure mechanism behavior of the R-SACC in the two zones. After that, the XRD/TGA and SEM/EDS of different samples were performed to support the recorded strength and further explain the stability of the structure at each temperature. These were then compared to that of the control sample $\left(20^{\circ} \mathrm{C}\right)$.

\section{Results and discussion}

\subsection{Image analysis of the samples' appearance}

Fig. 4 shows the color change of the external surface of the R-SACC. When heated to a certain temperature, R-SACC changes color. The R-SACC containing limestone aggregates will turn hurricane at approximately $50^{\circ}$ to $70^{\circ} \mathrm{C}$, rolling stone at about $100^{\circ} \mathrm{C}$, and tapa color at $120^{\circ} \mathrm{C}$. The color change of heated R-SACC results principally from the water removal and dehydration of the R-SAC paste, but is also caused by the transformations occurring within the aggregate. 

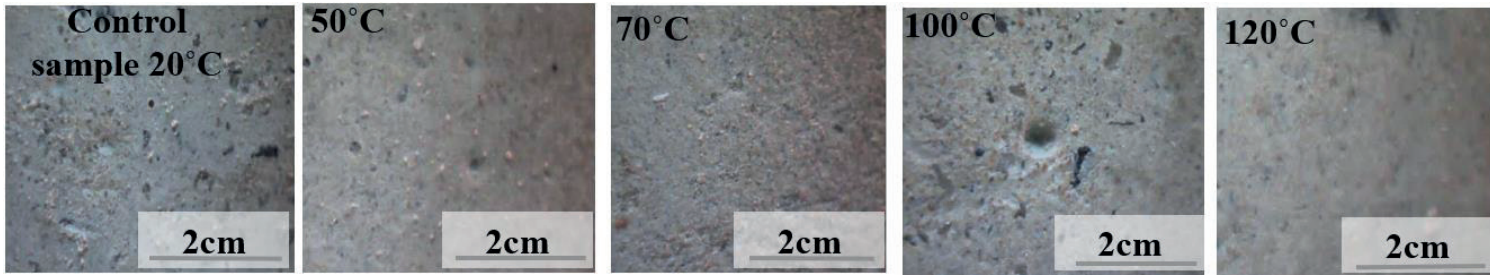

Fig. 4 Specimen color change appearances at elevated temperature: external surface of the concrete specimens immediately after removal from the furnace

As shown in Fig. 5(a), the mean gray values were found to be generally increasing with the rise in temperature. The most intense color change occurred at $100^{\circ}$ and $120^{\circ} \mathrm{C}$. Fig. 5(b) presents counts of pixel intensity that increase with temperature as well, and could be a clear indicator of the strength decreasing when exposed to those temperatures. This may be used to evaluate the actual temperature reached by the R-SACC structure when affected by fire.

\subsection{Analysis of cracks: microscopic images}

Fig. 6 shows the microscopic images of cracks in four samples at different temperatures. The width of the cracks in the samples heated to $50^{\circ} \mathrm{C}$ varied between 0.06 and $0.09 \mathrm{~mm}$; at $70^{\circ} \mathrm{C}$, it varied between 0.1 and $0.14 \mathrm{~mm}$; at $100^{\circ} \mathrm{C}$, it varied between 0.14 and $0.16 \mathrm{~mm}$; and at $120^{\circ} \mathrm{C}$, it varied between 0.17 and $0.30 \mathrm{~mm}$. The crack width was found to increase as the temperature increased, consistent with the internal structure observation (Fig. 7), the lower mass changes and the lower strength measurement recorded at higher temperatures.

\subsubsection{Ultrasonic test of the concrete}

Fig. 8 shows typical ultrasonic waveforms for the control sample at $20^{\circ}$, as well as at $50^{\circ}, 70^{\circ}, 100^{\circ}$ and $120^{\circ} \mathrm{C}$, obtained in the pre-cracking stage and after exposure for $4 \mathrm{hrs}$. The transmitting times and amplitude values are acquired from the head wave of the ultrasonic waveform. The transmitting times were found to increase and the amplitude values decreased as the temperature increased, as shown in Table 4. This is due to the cracks, which have
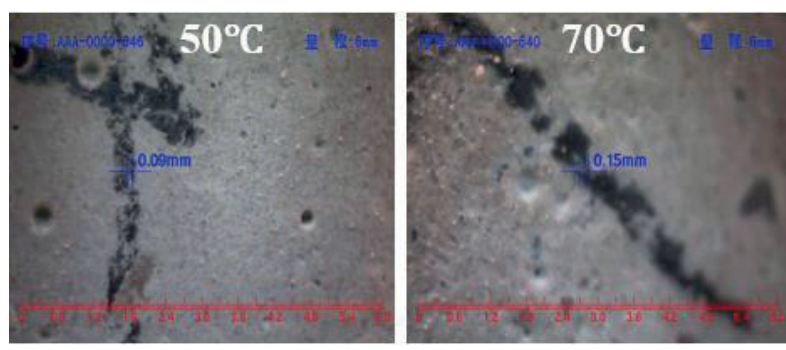

Fig. 6 Microscopic crack image of the sample after exposure to different temperatures
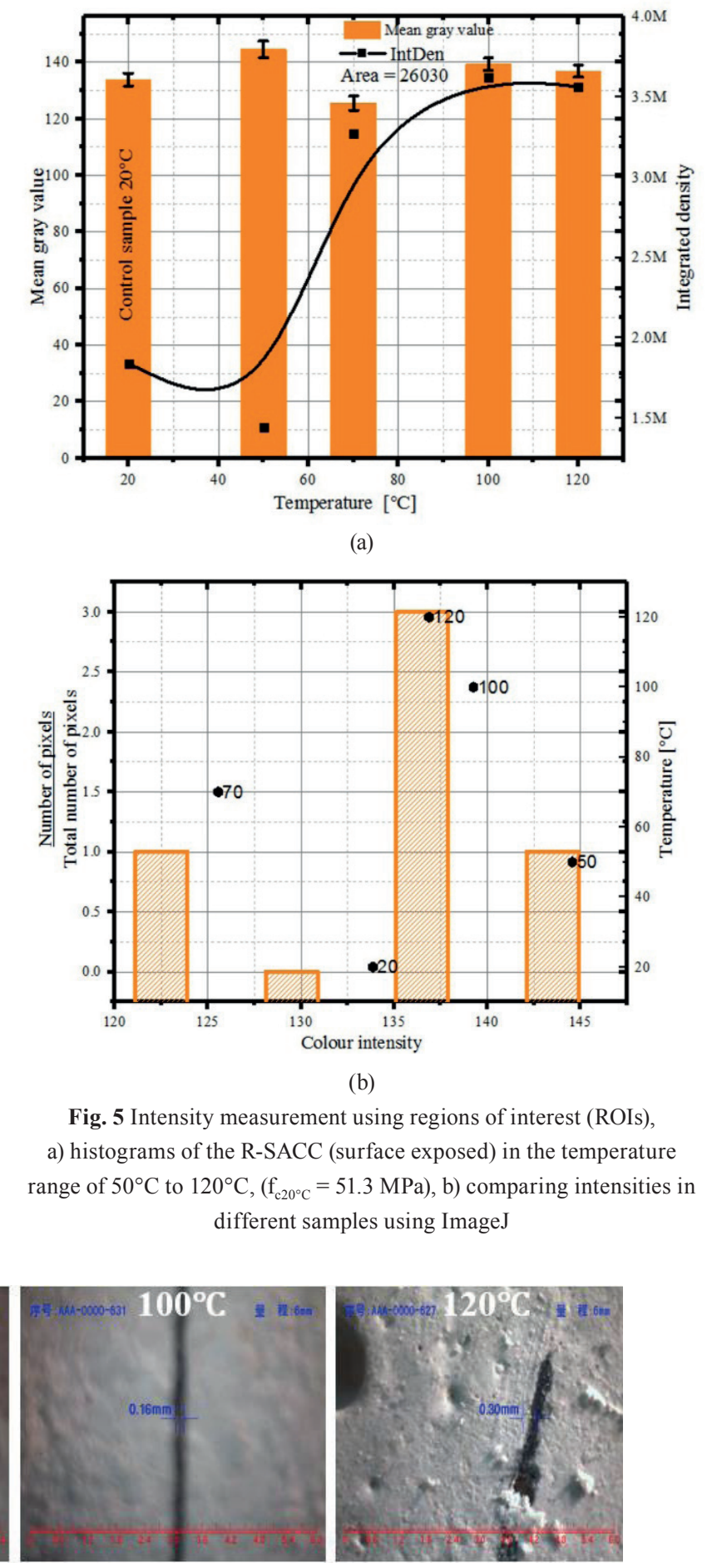

(a)

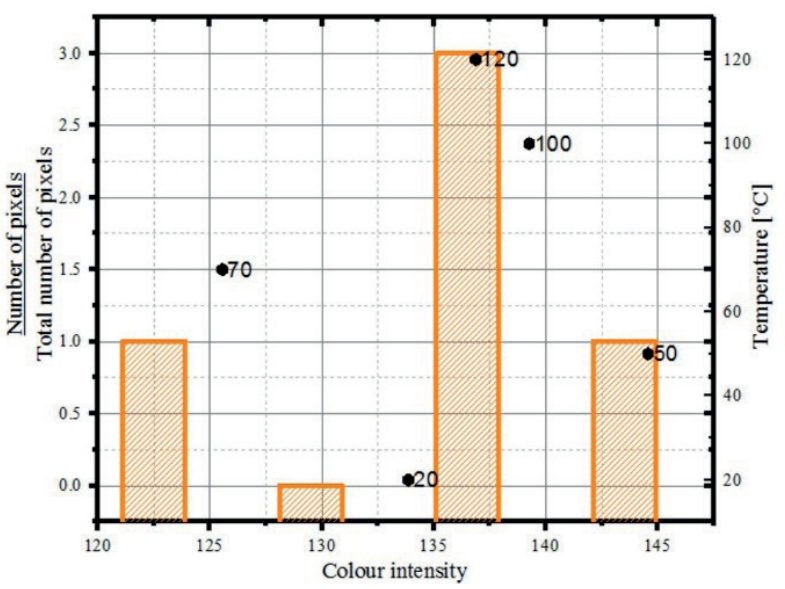

(b)

Fig. 5 Intensity measurement using regions of interest (ROIs), a) histograms of the R-SACC (surface exposed) in the temperature range of $50^{\circ} \mathrm{C}$ to $\left.120^{\circ} \mathrm{C},\left(f_{c 20^{\circ} \mathrm{C}}=51.3 \mathrm{MPa}\right), \mathrm{b}\right)$ comparing intensities in different samples using ImageJ 

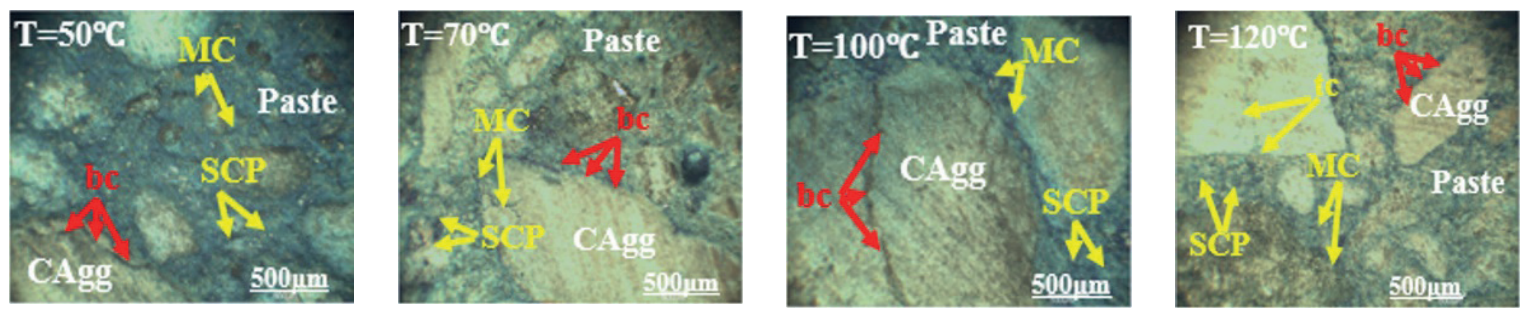

Fig. 7 Low-power stereomicroscope images from interior section of R-SACC affected. The images show heated induction: SCP = small capillary pores; $\mathrm{MC}=$ micro-cracks; $\mathrm{BC}=$ boundary crack, $\mathrm{TC}=$ transgranular crack .

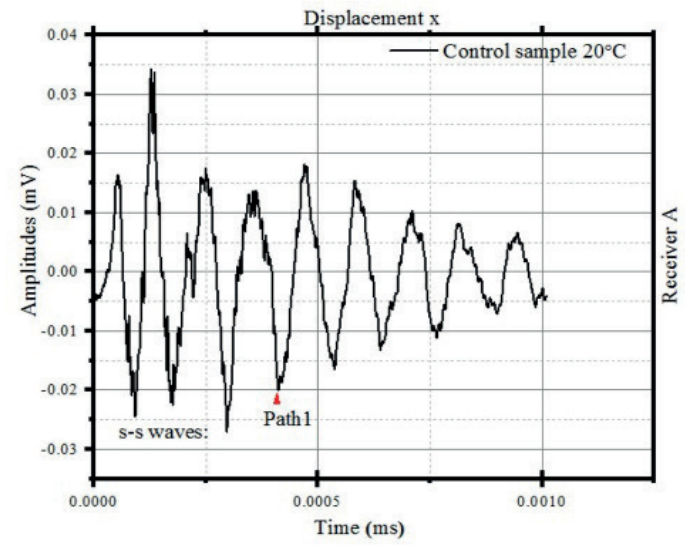

(a) Control sample $20^{\circ} \mathrm{C}$

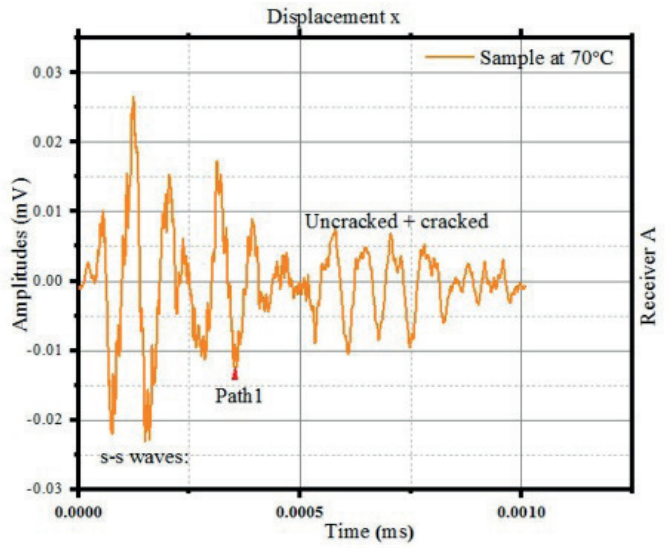

(c) Control sample $70^{\circ} \mathrm{C}$

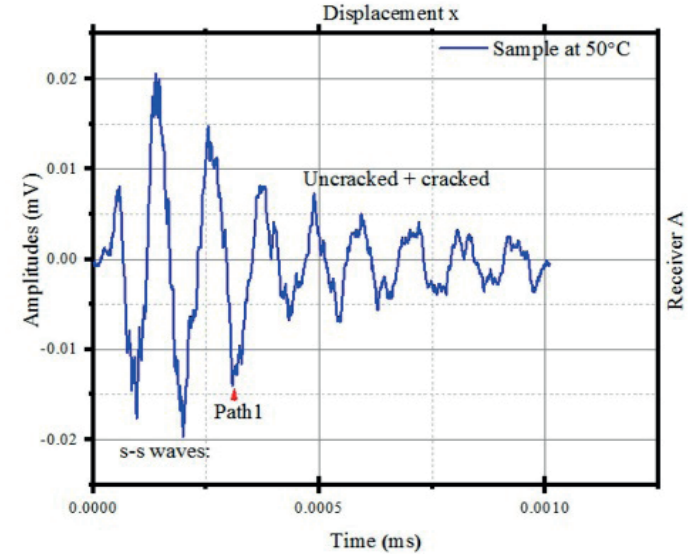

(b) Control sample $50^{\circ} \mathrm{C}$

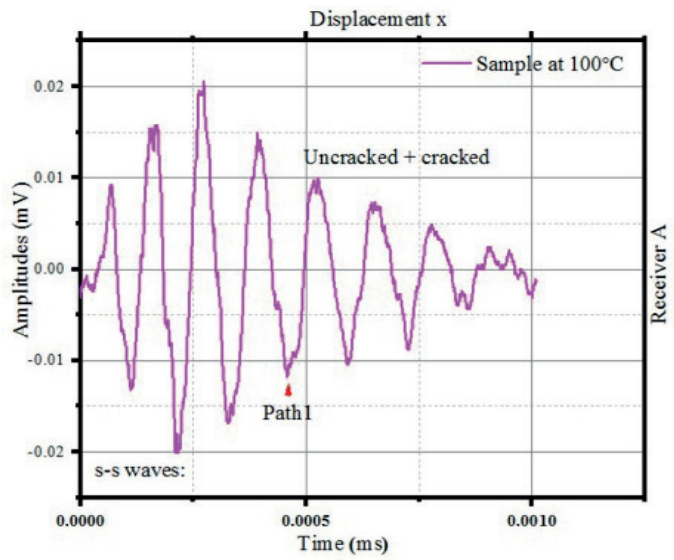

(d) Control sample $100^{\circ} \mathrm{C}$

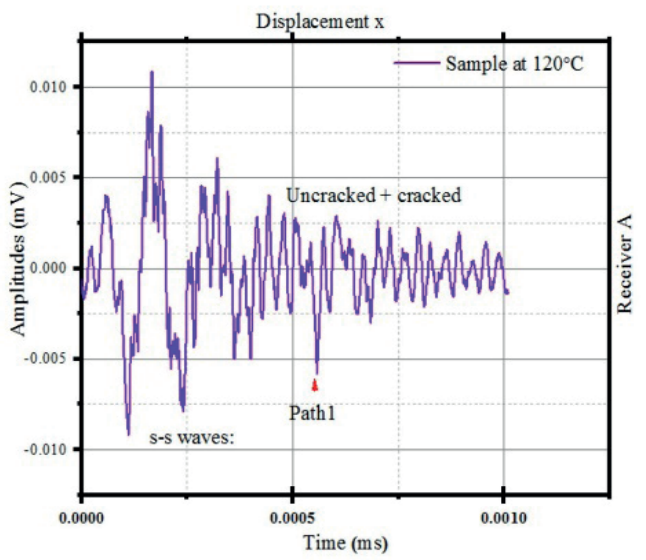

(e) Control sample $120^{\circ} \mathrm{C}$

Fig. 8 Ultrasonic diagrams before and after exposure to elevated temperatures, showing how the sample internally changes (or is destroyed) as the temperature increases 
Table 4 Impact of long-term heating characterized by ultrasonic analysis

\begin{tabular}{lccccc}
\hline $\begin{array}{l}\text { Tested } \\
\text { parameters }\end{array}$ & $\begin{array}{c}\text { Before } \\
\text { heating }\end{array}$ & \multicolumn{4}{c}{ After heating } \\
\hline $\begin{array}{l}\text { Temperature } \\
\begin{array}{l}\text { Average } \\
\text { arrival time }\end{array}\end{array}$ & $1.28 \mathrm{~ms}$ & $50^{\circ} \mathrm{C}$ & $70^{\circ} \mathrm{C}$ & $100^{\circ} \mathrm{C}$ & $120^{\circ} \mathrm{C}$ \\
$\begin{array}{l}\text { Average } \\
\text { amplitude }\end{array}$ & $0.03 \mathrm{mV}$ & 0.02 & 0.02 & $0.02 \mathrm{mV}$ & $0.01 \mathrm{mV}$ \\
$\begin{array}{l}\text { Change in } \\
\text { attenuation }\end{array}$ & & $\mathrm{mV}$ & $\mathrm{mV}$ & $2.71 \mathrm{~ms}$ & $2.86 \mathrm{~ms}$ \\
\hline
\end{tabular}

a strong interference with the propagation of the ultrasonic wave, leading to a longer transmitting time, small amplitude values, and unstable waveforms.

The R-SACC samples tested at normal temperature $\left(20^{\circ} \mathrm{C}\right)$ had the smallest transmitting time and the largest amplitude value, which indicates that the defects inside those samples tested before heating to different temperatures had a greater homogeneity and compactness. After heating, the peak-to-peak variation of those values was less evident, highlighting the severe effect that exposure to this range of temperatures for an extensive period can have on R-SACC. The waveform change may be caused by the energy attenuation of the ultrasonic wave during the propagation process, which encounters many microcracks. The ultrasonic wave encounters multiple reflections at the concrete interface, leading to the waveform attenuation and causing the non-reflecting waves observed when samples are heated. This result is correlated with the interior and exterior cracks observed on the surface of the samples as the temperature increases.

\subsection{Rebound hammer number (RHN)}

The rebound hammer allowed us to evaluate the hardness of the R-SACC after exposure. The output of the rebound hammer is referred to as a rebound number and corresponds with the surface hardness of the R-SACC. This method enables us to evaluate, in situ, the surface hardness of the R-SACC. Fig. 9 shows the interpretation of the RHN results. Using the average RHN results obtained for each sample, it was concluded that the heat-affected sample lost $5-23 \%$ of its strength from $50^{\circ} \mathrm{C}$ to $100^{\circ} \mathrm{C}$, relative to the JGJ/T23-2001 [34] recommendation; R-SACC with this amount of strength loss is still acceptable for use but requires adequate rehabilitation. Samples at $120^{\circ} \mathrm{C}$ were the most severely affected by heat, as about $28 \%$ of the samples' strength was lost, suggesting that R-SACC members subjected to temperature above $120^{\circ} \mathrm{C}$ must be considered not serviceable. Table 5 summarizes the changes in properties of the R-SACC after extended heating.
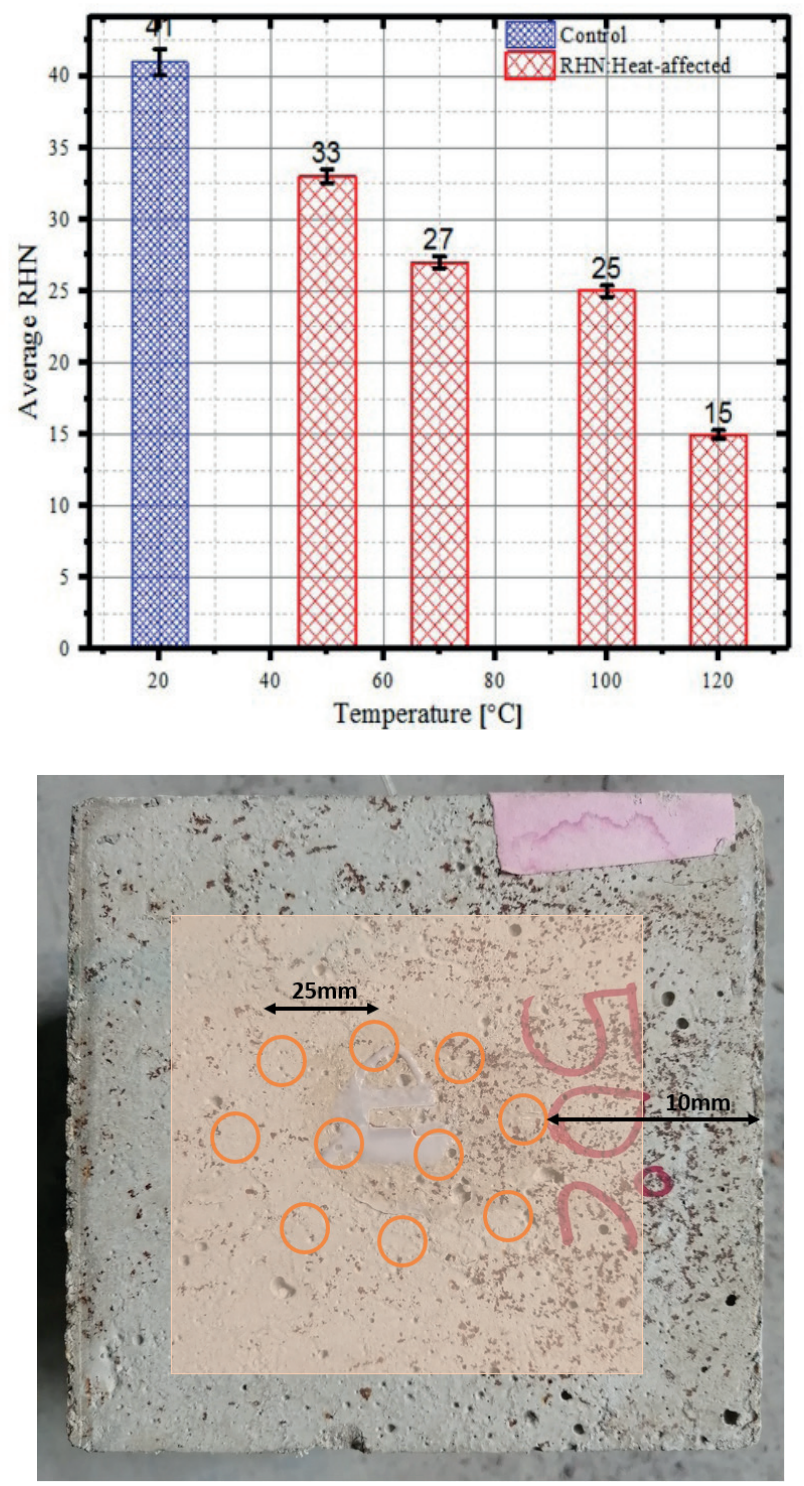

Fig. 9 Rebound hammer number test results

Table 5 Changes in properties of the samples after extended heating

\begin{tabular}{|c|c|c|}
\hline $\mathrm{S} / \mathrm{N}$ & $\begin{array}{c}\text { R-SACC and R-SAC surface } \\
\text { appearance }\end{array}$ & $\begin{array}{l}\text { Probable } \\
\text { temperature attained }\end{array}$ \\
\hline 1 & $\begin{array}{l}\text { Spalled and smirched R-SACC } \\
\text { surface, small-width cracks }\end{array}$ & $50^{\circ} \mathrm{C}$ to $70^{\circ} \mathrm{C}$ \\
\hline 2 & $\begin{array}{c}\text { yellowish and whitish color as } \\
\text { temperature rises; some instances of } \\
\text { cracks }\end{array}$ & $70^{\circ} \mathrm{C}$ to $100^{\circ} \mathrm{C}$ \\
\hline 3 & $\begin{array}{l}\text { Removal of R-SACC cover aggregates } \\
\text { are exposed at some places, } \\
\text { observation of some pop-out splitting } \\
\text { on the surface of the samples }\end{array}$ & $\begin{array}{c}100^{\circ} \mathrm{C} \text { to } 120^{\circ} \mathrm{C} \\
\text { above }\end{array}$ \\
\hline
\end{tabular}




\subsection{Mass change analysis}

The mass of the sample was found to be decreasing: $R_{m}=M_{0}-M_{i}$. Fig. 10 shows the mass change of the different samples after exposure to different temperatures. The mass of the control sample of cement paste was $0.016 \mathrm{~kg}$ for the $20 \times 20 \times 20 \mathrm{~mm}$ sample, $0.625 \mathrm{~kg}$ for the $40 \times 40 \times 150 \mathrm{~mm}$ sample, and $2.47 \mathrm{~kg}$ for the $100 \times 100 \times 100 \mathrm{~mm}$ sample. Table 6 shows the mass decrease by percentage.

Compared with the control sample, the mass was found to decrease, because the R-SAC samples exposed to elevated temperatures experience greater dehydration. The rising
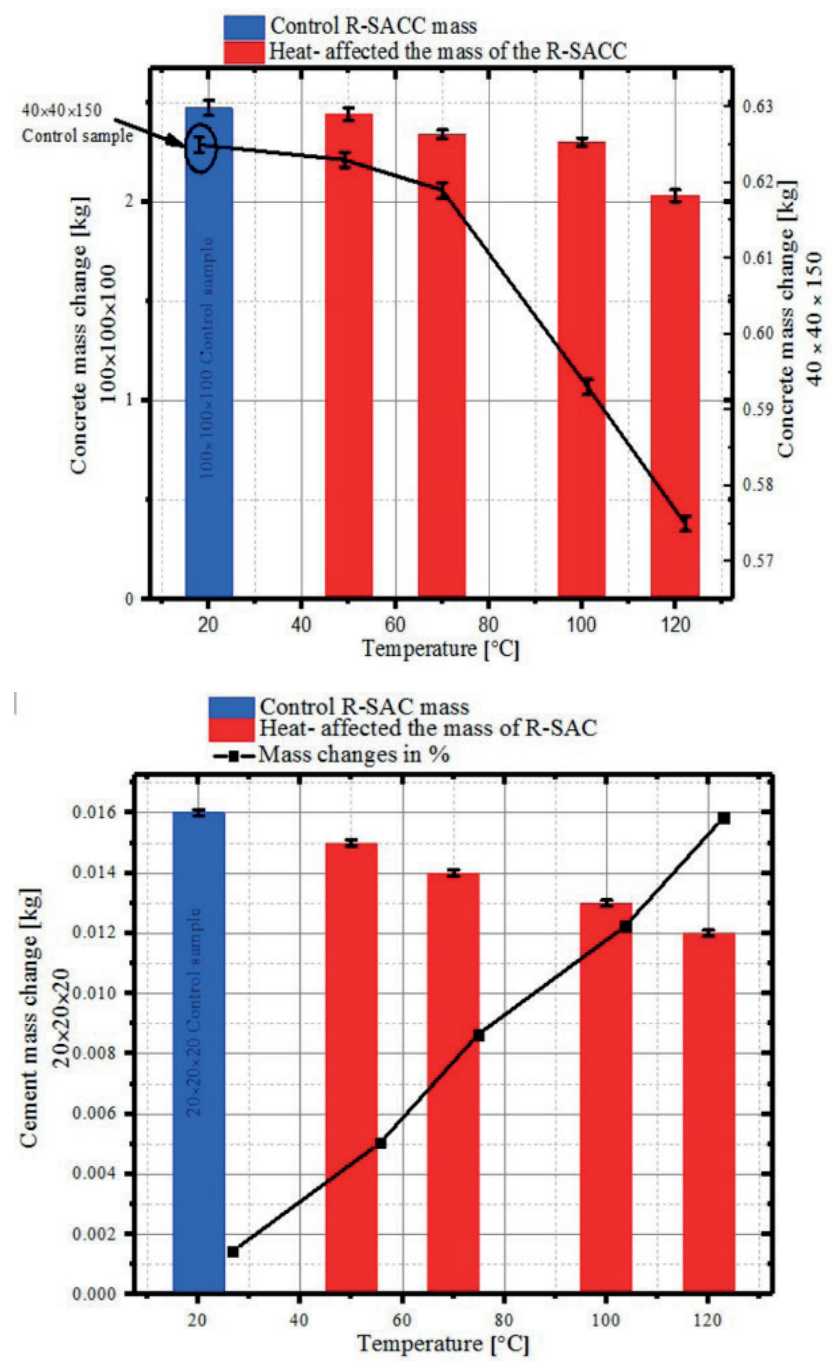

Fig. 10 Mass change of sample

Table 6 Mass changes by percentage of the samples

\begin{tabular}{lccccc}
\hline \multirow{2}{*}{ Sample } & $\begin{array}{c}\text { Mass changes } \\
\text { by } \%\end{array}$ & \multicolumn{4}{c}{ Temperature $\left({ }^{\circ} \mathrm{C}\right)$} \\
\hline $20 \times 20 \times 20 \mathrm{~mm}$ & & 70 & 100 & 120 \\
$40 \times 40 \times 150 \mathrm{~mm}$ & & 6.25 & 12.5 & 18.75 & 25 \\
$100 \times 100 \times 100 \mathrm{~mm}$ & & 0.32 & 0.96 & 5.12 & 8 \\
\hline
\end{tabular}

temperature induces deterioration due to the dehydration-related decomposition of ettringite, which creates pores followed by cracks. The surface of the R-SACC has a larger crack density. According to the test results in Fig. 11, the length of the samples shrank slightly with heating. Compared with the initial length of $20 \mathrm{~mm}$ at $20^{\circ} \mathrm{C}$, it became $19.79 \mathrm{~mm}$ at $120^{\circ} \mathrm{C}$; the cement sample was in a shrunken state, and the R-SACC's initial length of $40 \mathrm{~mm}$ at $20^{\circ} \mathrm{C}$ changed to $39.85 \mathrm{~mm}$ at $120^{\circ} \mathrm{C}$. The shrinkage amount of the R-SAC paste was far greater than the shrinkage value of R-SACC.

\subsection{Mechanical properties}

\subsubsection{Compressive strength of the R-SACC}

The change in compressive strength of the R-SACC after exposure to elevated temperature was closely related to the concrete structure and the properties of each component
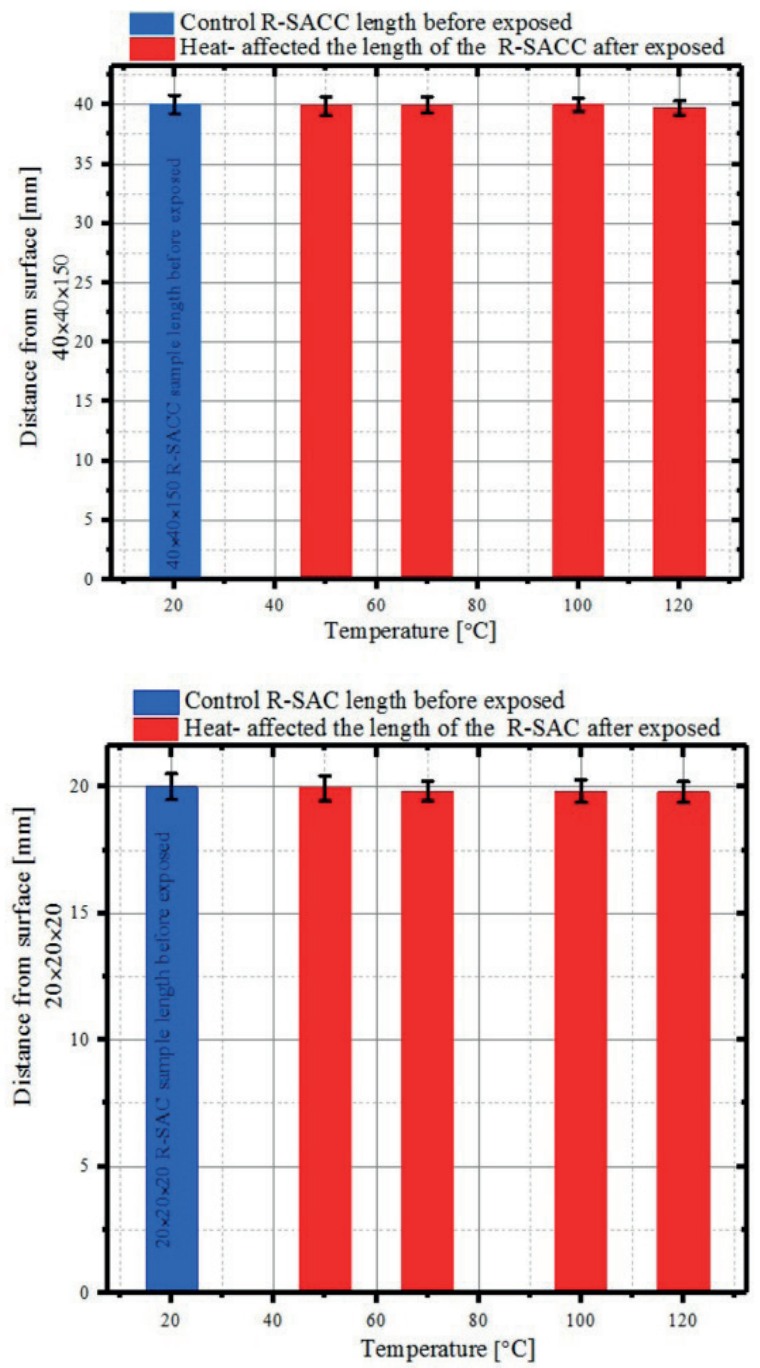

Fig. 11 Progress of shrinkage with temperature as a function of distance from the drying surface 
material. Concerning the concrete itself, three main factors affect the change in strength: dehydration of cement-hydrated products; crystal structure transformation and other damage caused by aggregates; and damage to the interface layer between aggregate and cement paste. The experiment studied the change of compressive strength in the zone of ettringite persistence and the zone of ettringite decomposition after exposure to elevated temperatures. The results are shown in Fig. 12 . Below $50^{\circ} \mathrm{C}$, the compressive strength of concrete shows a relatively low decreasing trend, but from $70^{\circ}$ to $120^{\circ} \mathrm{C}$, the compressive strength drops sharply. Fig. 12(a) shows that the compressive strength of pure R-SAC paste decreases with increasing temperature as well as that of R-SACC, and both reach the minimum value
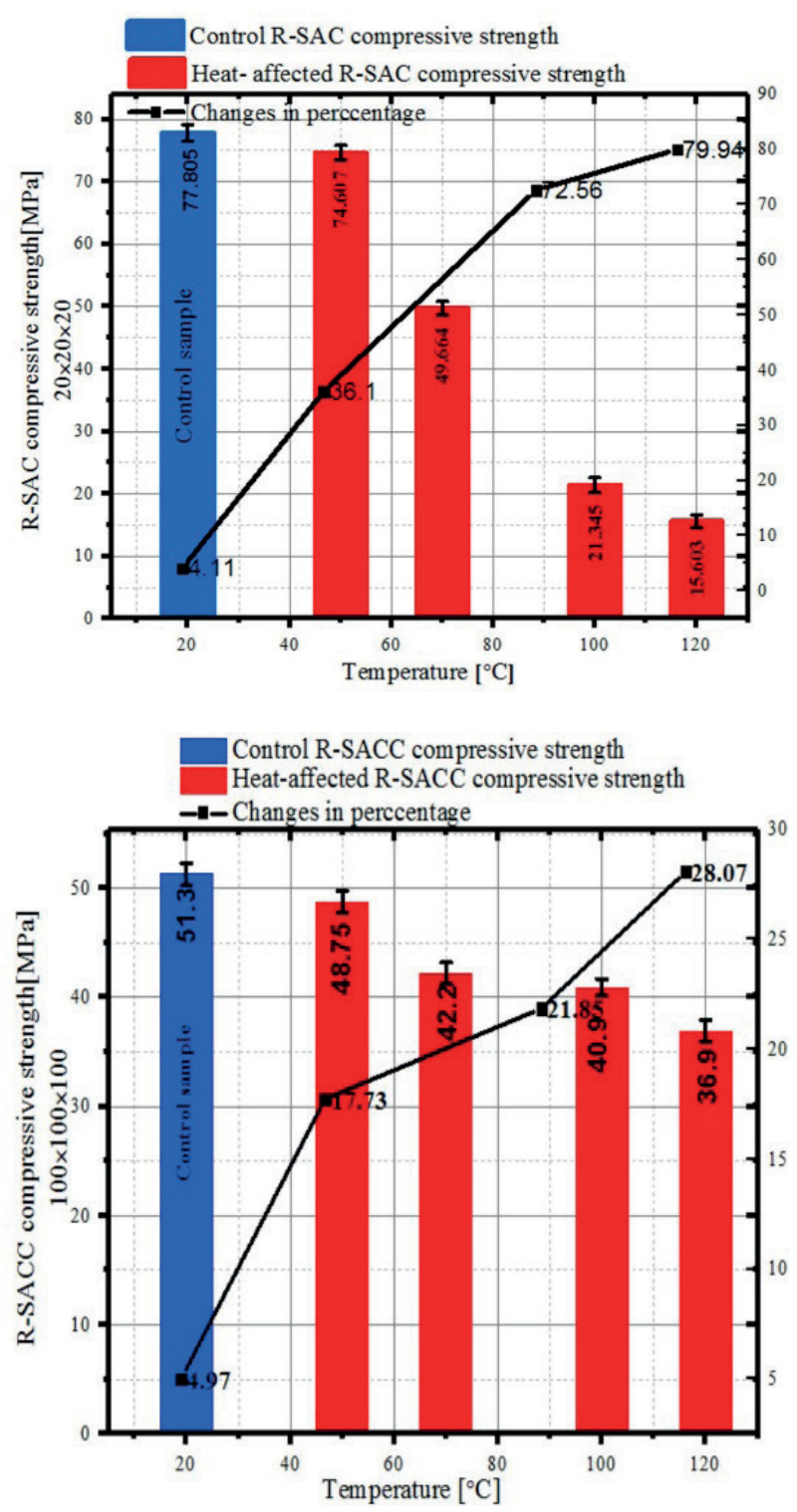

Fig. 12 Compressive strengths of R-SACC and R-SAC relative to temperature at $120^{\circ}$ and $100^{\circ} \mathrm{C}$. As the temperature rises from room temperature until it is higher than $70^{\circ} \mathrm{C}$, shrinkage occurs and the compressive strength declines noticeably.

The compressive strength of R-SACC continues to decrease with increasing temperature, but the decrease is greater between $70^{\circ}$ and $120^{\circ} \mathrm{C}$. In addition, between $70^{\circ}$ and $120^{\circ} \mathrm{C}$, some of the specimens in the R-SACC cracked, and most of the cracks occurred at the corners. The reasons for the bursting of R-SACC are complex and have many influencing factors, such as heating rate, thermal stress, density, amount of moisture contained, and aggregate mineral composition. Although the bursting mechanism has yet to be identified, two main explanations have been proposed: the water vapor pressure mechanism and the thermal stress mechanism [35, 36]. Research by Thomas et al. [37] and Tchekwagep et al. [30] pointed out that the increase in porosity after exposure to elevated temperatures is one of the main reasons for strength loss.

\subsubsection{Tensile strength of R-SACC}

Elevated-temperature tensile strength is an important factor in evaluating the extent of spalling and fire resistance of concrete structures. The data collected in this study can be used as an input parameter in computer models to evaluate the spalling and fire resistance of R-SACC structural members. Fig. 13 shows the variation of tensile strength as a function of temperature. The decrease in tensile strength of the R-SACC with increasing temperature can be attributed to the weak microstructure observed internally in the R-SACC, allowing initiation of micro-cracks. At $50^{\circ} \mathrm{C}$, R-SACC loses about $32.4 \%$ of its initial tensile strength. Beyond $50^{\circ} \mathrm{C}$, the tensile strength of R-SACC

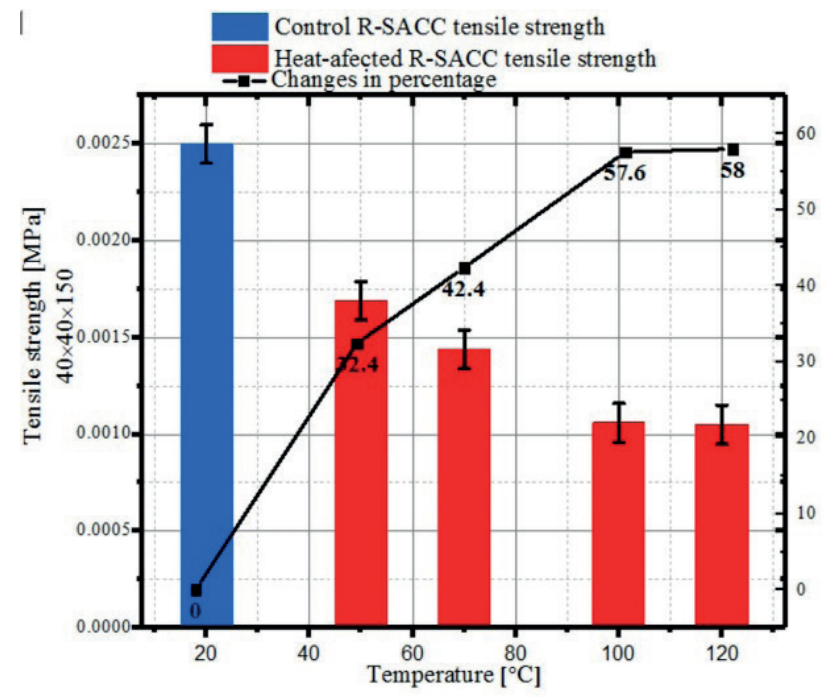

Fig. 13 Tensile strength of R-SACC as a function of temperature 
decreases at a rapid rate due to more pronounced thermal damage in the form of micro-cracks, falling to about $58 \%$ of its initial strength at $120^{\circ} \mathrm{C}$.

\subsubsection{Flexural performance of R-SACC}

Test data indicate that exposure to elevated temperatures causes deterioration in the flexural strength of the R-SACC (Fig. 14). At $50^{\circ} \mathrm{C}$ and higher, exposure to heat for an extended period causes the dehydration of the R-SAC, mostly the ettringite, which will have an impact on strength measurement. The amount of strength lost by the R-SACC at different temperatures varies considerably.

Residual strength (Fig. 15) of both R-SACC and R-SAC drops in a similar pattern as temperature rises. That implies that the sample carrying load capacity is dropping, which will eventually lead to the failure of the sample. In

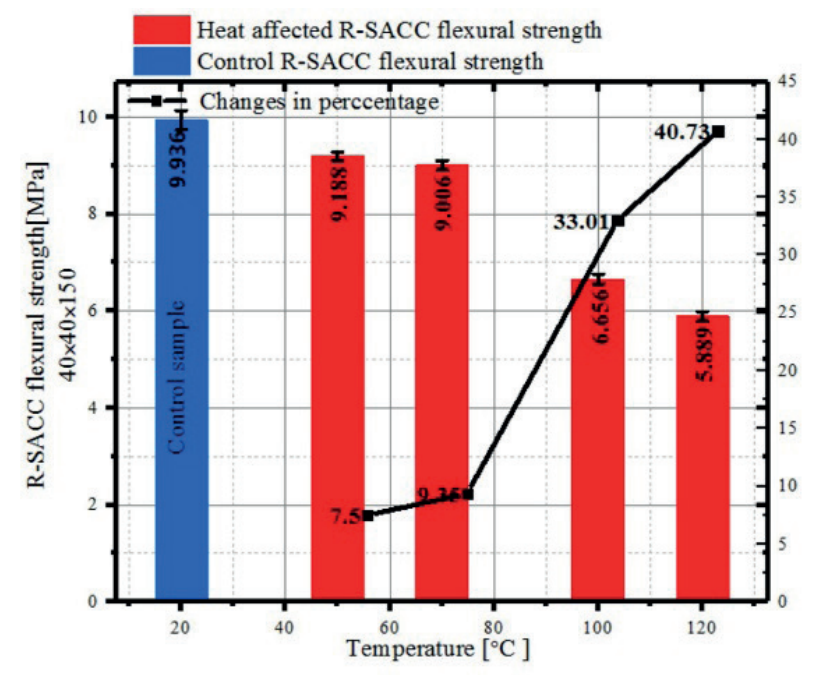

Fig. 14 Flexural properties after exposure to elevated temperatures

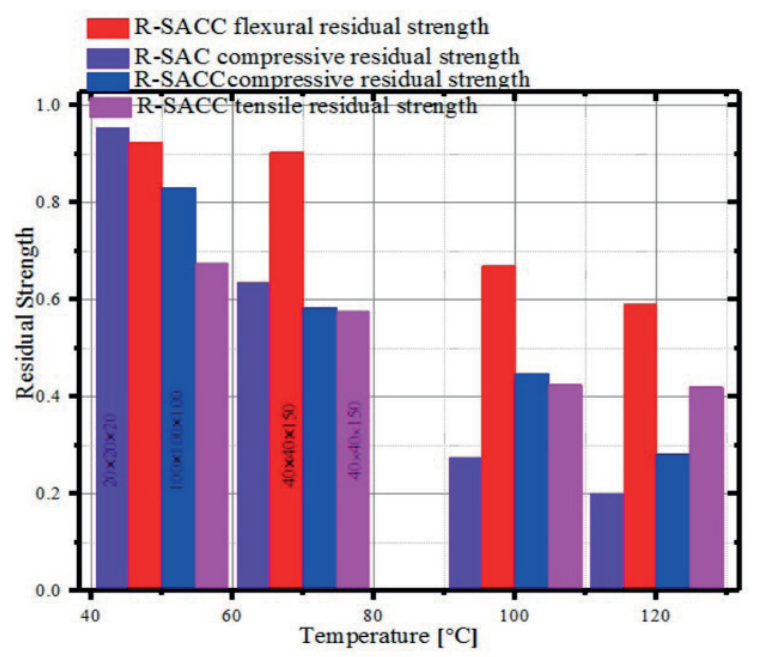

Fig. 15 Residual strength of the mechanical properties of the R-SACC and R-SAC accord with ASTM specification 936-96, the R-SACC samples exposed to temperatures above $50^{\circ} \mathrm{C}$ should be demolished, not repaired, because the strength drops to 42.2 MPa which is not acceptable.

\subsection{Strain-stress}

Fig. 16 shows the appearance after exposure to heat, followed by load application. The slope of the stress-strain deformation curve decreases with rising temperature. The R-SACC stress-strain behavior for the control sample $\left(20^{\circ} \mathrm{C}\right)$ displays a linear-elastic curve for the first $80 \%$ of its strength, followed by strain softening to rupture. The behavior of all the thermally exposed samples follows a classical elasto-plastic (strain-softening) curve with a generally softer response for samples exposed to elevated temperatures. The stress-strain variation curves can be attributed to the testing conditions, moisture percentage inside the R-SACC (which was $8.2 \%$ at $20^{\circ} \mathrm{C}, 9.5 \%$ at $50^{\circ} \mathrm{C}, 8.7 \%$ at $70^{\circ} \mathrm{C}, 9.5 \%$ at $100^{\circ} \mathrm{C}$ and $9.3 \%$ at $120^{\circ} \mathrm{C}$ ), and the different exposure temperature that affect the samples.

At $100^{\circ}$ and $120^{\circ} \mathrm{C}$, the characteristic trend is elastic behavior starting with a shallow slope (shallower than at $20^{\circ} \mathrm{C}$ ), followed by gradual decrease in slope until it fails. At $50^{\circ} \mathrm{C}$, the initial elastic behavior was similar to that at $20^{\circ} \mathrm{C}$ but then changed promptly to a very low slope (i.e., high change in strain with a smaller change in stress, more of a visco-elastic and plastic nature) with less decrease in slope until failure. The variations in the stress-strain curves can be attributed to the interior degradation observed through the stereomicroscope as well as by the MIP (mercury intrusion porosimetry) observation. The results indicate a denser area of microstructure pores with diameter between 2 and $50 \mathrm{~nm}$, caused by the heat, and the pores become larger when a load is applied.
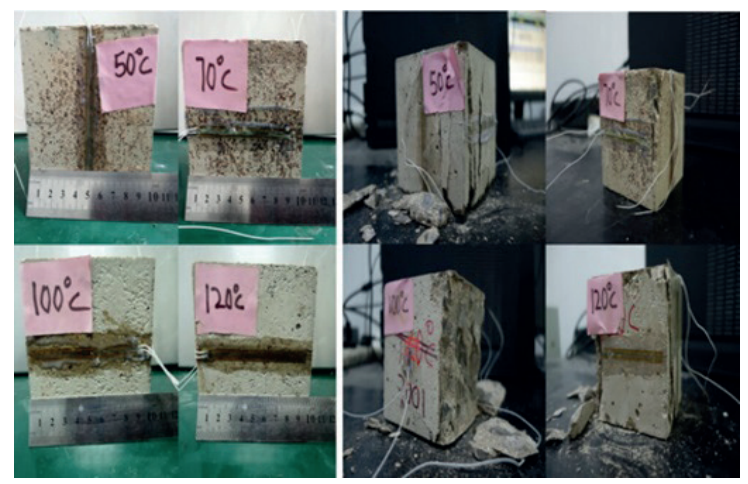

Fig. 16 Appearance of the R-SACC specimens immediately after removal from the furnace, and crack damage after exposure to elevated temperature and loading 
The compressive stress-strain curve of the R-SACC at $50^{\circ}, 70^{\circ}, 100^{\circ}$, and $120^{\circ} \mathrm{C}$ shows distinctly that stress has a tendency to decline and its peak evidently descends and moves toward the right-hand side as the testing temperature increases. These differences might be due to vapor evolvement during heating, or the thermal behavior difference observed on the surface of the samples coming out of the furnace. At $50^{\circ}, 70^{\circ}, 100^{\circ}$, and $120^{\circ} \mathrm{C}$, micro-cracks between the coarse aggregate and cement paste interface were visible to the eye, and these cracks contribute to the descending stress-strain curve observed when load was applied. The stress-strain curve drops perceptibly, as observed in Fig. 17, as the temperature increases.

\subsection{Poisson's ratio}

Poisson's ratio $(v)$ was determined for each sample by dividing the vertical strain by the horizontal strain obtained through strain gauges, for the short-term instantaneous value. The average values of Poisson's ratio for most of the sample tests at different temperatures were in the range from 0.25 to 0.10 with large scattering (Fig. 18). Elevated temperatures caused both horizontal and vertical strain to increase by a similar amount, so the net effect on Poisson's ratio was small. The effect of both temperature exposure and moisture content on Poisson's ratio seemed to be significant. The reason why Poisson's ratio varied somewhat is that it is difficult to change the temperature and moisture contented in the entire sample at the same rate during testing. When the tests are conducted, the moisture inside the sample may change some as well and at an uneven rate, thus changing Poisson's ratio.

\subsection{Thermal mechanism analysis of the R-SAC paste}

As the temperature rises to about $70^{\circ}$ to $100^{\circ} \mathrm{C}$, the hydrated ettringite crystal water and structural water in the R-SAC paste are continuously released, and the cement paste structure becomes denser. At this point, the dehydration and shrinkage of R-SACC dominate. The overall behavior pattern of the R-SAC paste is shrinkage. When the temperature reaches $120^{\circ} \mathrm{C}$, the dehydration (principally of the ettringite) is complete. The dehydration-related shrinkage of the rapid cement paste is basically balanced with the thermal expansion. The volume of the R-SACC changes; the thermal expansion of the paste is more complicated than that of the R-SACC. In addition to the thermal expansion and dehydration shrinkage of the R-SACC, it is also affected by the thermal expansion of the aggregate and the change of crystal form. Summarizing the results of the various tests,

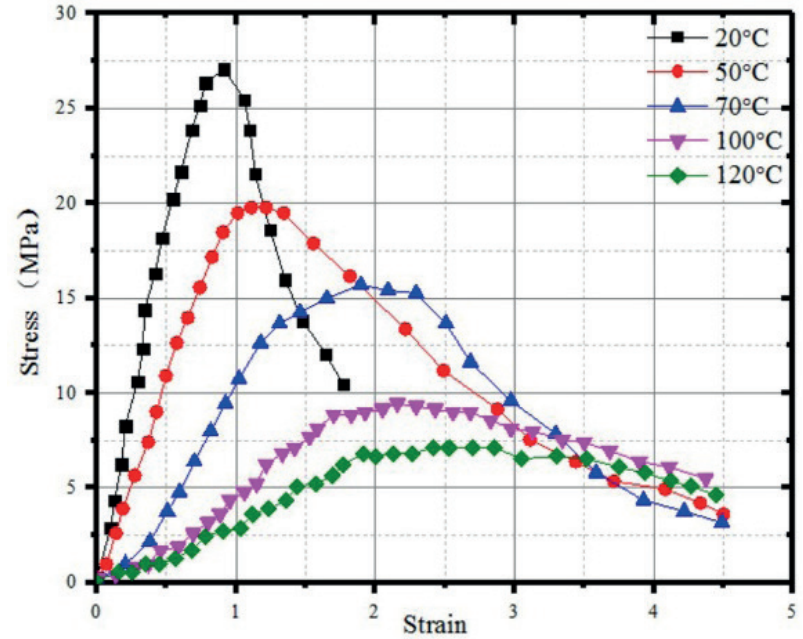

Fig. 17 Stress-strain curves of the R-SAC concrete

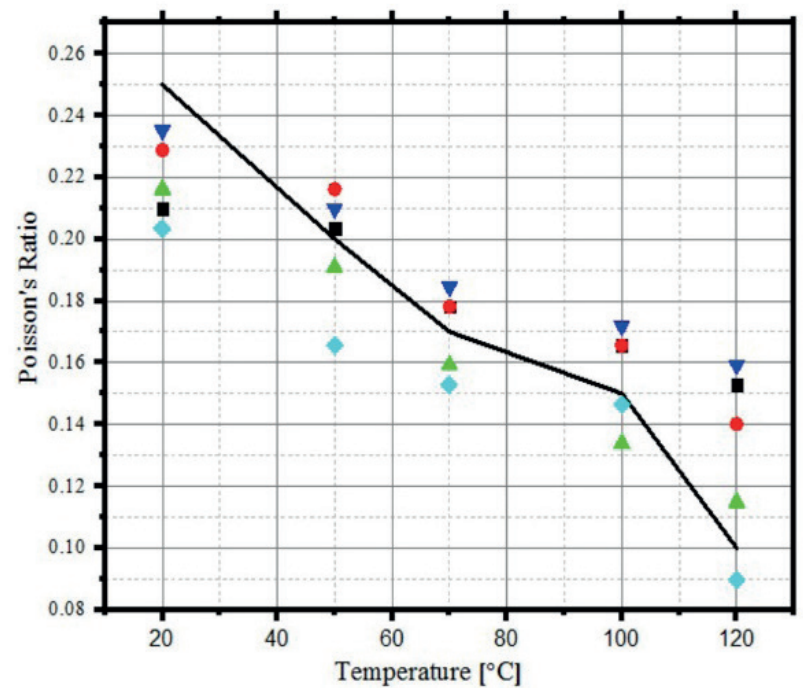

Fig. 18 Effect of temperature on Poisson's ratio

when the R-SAC paste is heated from room temperature to a temperature of $70^{\circ} \mathrm{C}$, the main loss occurs. The macroscopically adsorbed water in the pores and a small amount of hydrated calcium sulphoaluminate are not firmly bound to the crystallization water. The loss of this water has a significant effect on the volume of the R-SAC paste. At this point, each solid phase component of the cement paste itself is dominated by thermal expansion. The status of the $\mathrm{R}-\mathrm{SAC}$ sample as a whole is in an expanded state.

Fig. 19 shows the TG-DSC spectrum of the 28-day compound of the R-SAC paste. When the temperature increases to $120^{\circ} \mathrm{C}$, the ettringite completely disappears.

\subsubsection{X-ray diffraction (XRD) analysis}

The XRD spectra of the samples after exposure to different elevated temperature for 4 hours and at the control temperature are shown in Fig. 20. The spectrum of the diffractive 

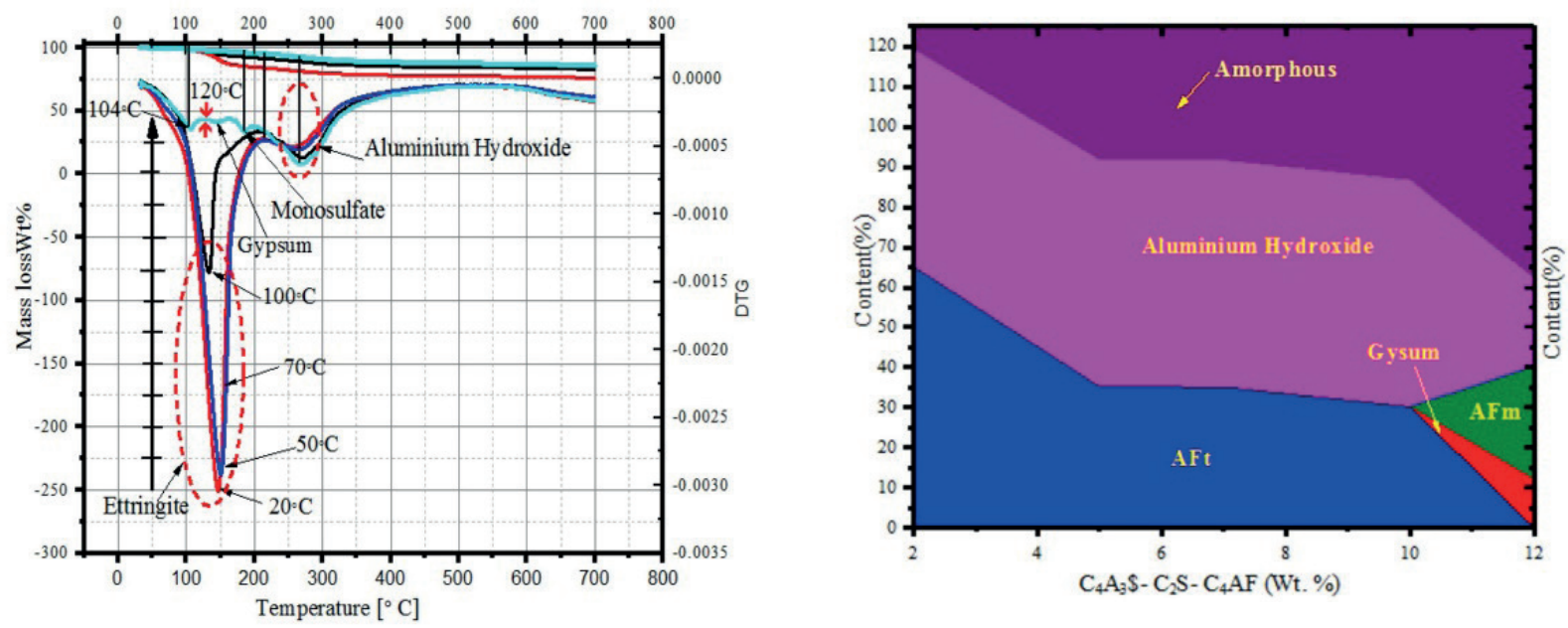

Fig. 19 Change in thermogravimetric curves of the R-SAC paste compound at various temperatures
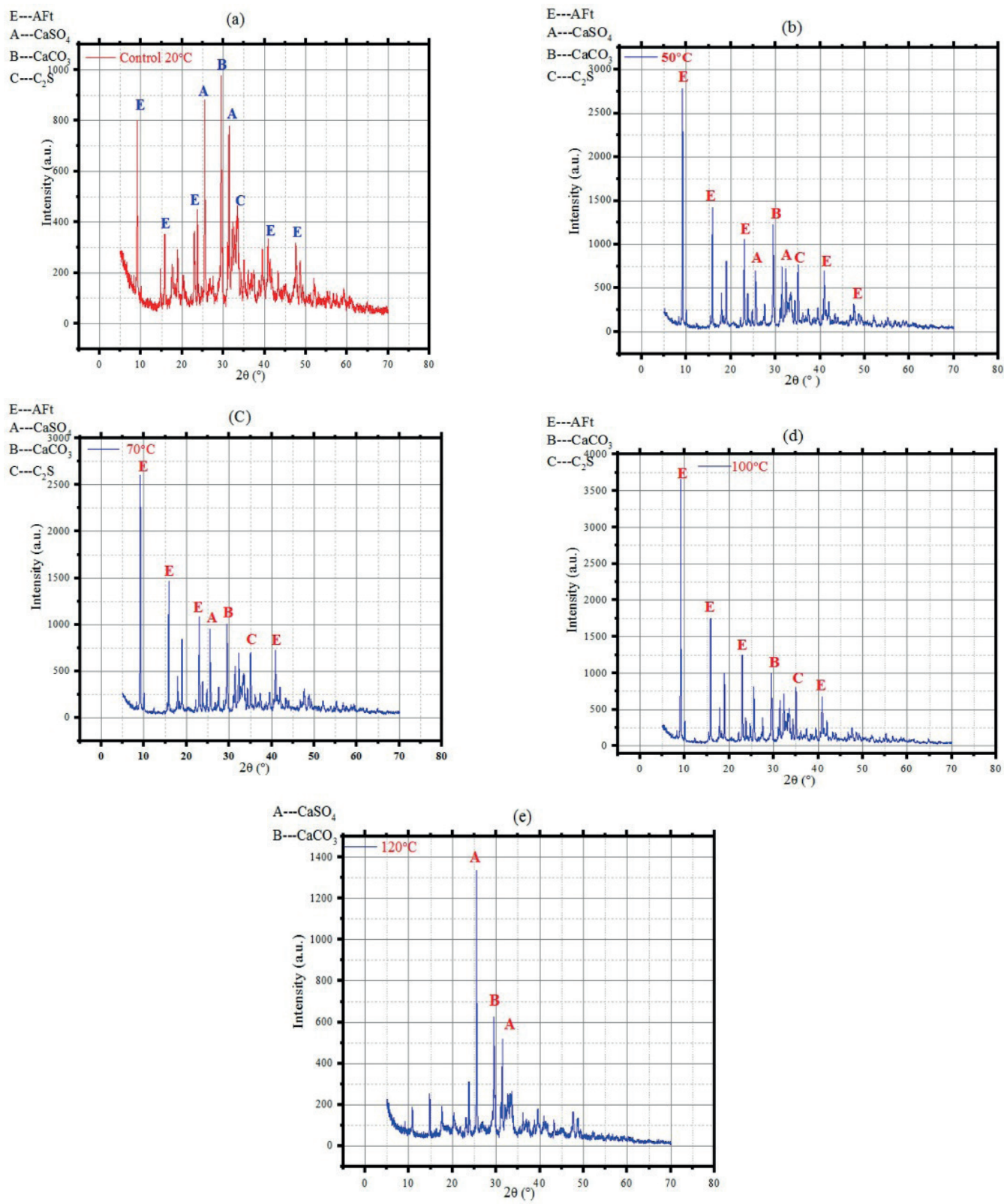

Fig. 20 XR spectra of the R-SAC paste after exposure to different temperatures 
crystal corresponds to the standard diffraction peak and there are a few impurity peaks, indicating ongoing dehydration as the temperature increased. Narrow and sharp diffraction peaks were found in all four samples at $T<70$. At the diffraction angles of $10^{\circ}$, higher than that of other samples, indicating that the $\mathrm{AFt}$ crystal formed at $100^{\circ} \mathrm{C}$ is more than the AFt crystal dehydrate in other samples.

It can be seen from the XRD pattern of the 28-day compound of the R-SAC powder cement paste (Fig. 20(a)) at room temperature that the main mineral component is a large amount of hydration product $A F t(d=9.92,5.11,3.867$, 2.77, 2.49, 2.206, $1.48,1.45$, and CaSO4 $(d=3.4988,2.8495$, 2.7971, 1.7270, and a small amount of $\mathrm{CaCO} 3(d=2.77$, $2.737,2.1819,2.16013,1.76$ ). However, after $100^{\circ} \mathrm{C}$, the standard XRD pattern of mineral powder cement after 28 days changed significantly: the diffraction peaks of $A F t$ had disappeared, the number of $\mathrm{CaSO} 4$ diffraction peaks had decreased significantly, the intensity had decreased, and a diffraction peak of $\mathrm{CaCO} 3$ appeared $(d=2.77,2.39)$. This indicates that above $100^{\circ} \mathrm{C}$, the mineral components of the powder of the R-SAC have obviously changed; the $A F t$ has completely decomposed.

\subsubsection{SEM/EDS analysis of the R-SAC paste}

We tested the R-SAC paste samples using SEM tools, to observe the micro-cracks with $\times 10.00$ magnification. The micro-cracks observed through SEM had diameters in the range of 1-20 nm. The micro-cracks seen in the SEM observation occupied only $0.1-0.2 \%$ of total porous volume, and thus, little influence of micro-cracks in macron is induced on the macroporous volume of the R-SAC paste. In SEM images, two parts of micro-cracks are observed. One part is identified around paste with a flat surface and seems to be more isolated.

The further part of micro-cracks is generated around dehydrated R-SAC paste, is entirely connected with a capillary pore network, and thus may have large impact on the pore network connectivity. Two parts of micro-cracks occupy 5.4 to $9.1 \%$ of total porous volume and are focused on the diameter of 20 to $100 \mathrm{~nm}$. The ImageJ of microcrack-removed images shows only a little variation of the curve form and peak size. Moreover, the pore connectivity is only slightly weakened. The ratio between surface-connected porous volume and total porous volume decreased from $84.0-85.3 \%$ to $81.3-82.4 \%$. Overall, despite the fact that the micro-cracks contribute to whole porous volume especially in SEM images, they have minimal impact on the pore size distribution.
These tests allowed a quick visual determination of the groups of different chemical compositions that constitute a complex material. They also enabled the identification of micro-cracks, as well as apprehending the deterioration of the AFt and C-S-H, followed by the formation of $A F m$ crystals (Fig. 21). At $120^{\circ} \mathrm{C}$, the pattern of cracks was more pronounced, and the R-SAC matrix was strongly deteriorated. Fig. 22 presents the control sample at ambient temperature $\left(20^{\circ} \mathrm{C}\right)$ and then some micrographs of the R-SACC sample after exposure to elevated temperatures. From a microstructural point of view, there was perceptible degradation of the R-SACC. According to various authors, $A F t$ and $(\mathrm{OH}) 3$ dehydrate. In Fig. 22, the SEM images at ambient temperature, no visible cracking could be distinguished, and the surface of the concrete did not exhibit deterioration. Between $50^{\circ}$ and $120^{\circ} \mathrm{C}$, physicochemical changes in the R-SAC paste and aggregates occurred. Comparing the images at $50^{\circ}$ and $70^{\circ} \mathrm{C}$, we can see that the network structure of R-SAC paste dehydration product after $100^{\circ} \mathrm{C}$ elevated temperature is broken, the number is reduced, and cracks appear. Furthermore, the R-SACC interface structure between the material and the cement is loose, and cracks appear. Fig. 23 shows the increasing of the nanoparticle size with the rise in temperature, which correlates with the polydispersity in percentage and is in accord with the dehydration phenomenon.

\subsection{Mercury intrusion porosimetry (MIP)}

The mercury intrusion curves provide the total porosity $(\tau)$ by percentage. The intrusion curves of the samples are shown in Fig. 24(a). The total pore volume of samples increased in conjunction with temperature increase. Porosity values ranged from a lowest value of $24 \%$ (control sample) to the highest value of $28.62 \%$ (sample at $120^{\circ} \mathrm{C}$ ). The volumes of capillary pores $(>1 \mathrm{~nm})$ of samples from $20^{\circ}$ to $70^{\circ} \mathrm{C}$ were very close. When the temperature changed from $70^{\circ}$ to $120^{\circ} \mathrm{C}$, both capillary pores $(>0.01 \mathrm{~nm})$ and gel pores $(<0.01 \mathrm{~nm})$ increased considerably. This may be due to the decomposition of AFt between $70^{\circ}$ and $120^{\circ} \mathrm{C}$. The pore size distribution differential curve is obtained by taking the slope of the pore size distribution curve log differential intrusion against pore sizes (Fig. 24(b)). Several peaks can be found in this curve. These peaks represent the pore diameters corresponding to the higher rate of mercury intrusion per change in pressure. These peaks are called "threshold" pore diameters. The threshold pore diameters of samples could be observed from plotting the $\log$ of differential intrusion versus pore size, as shown in 

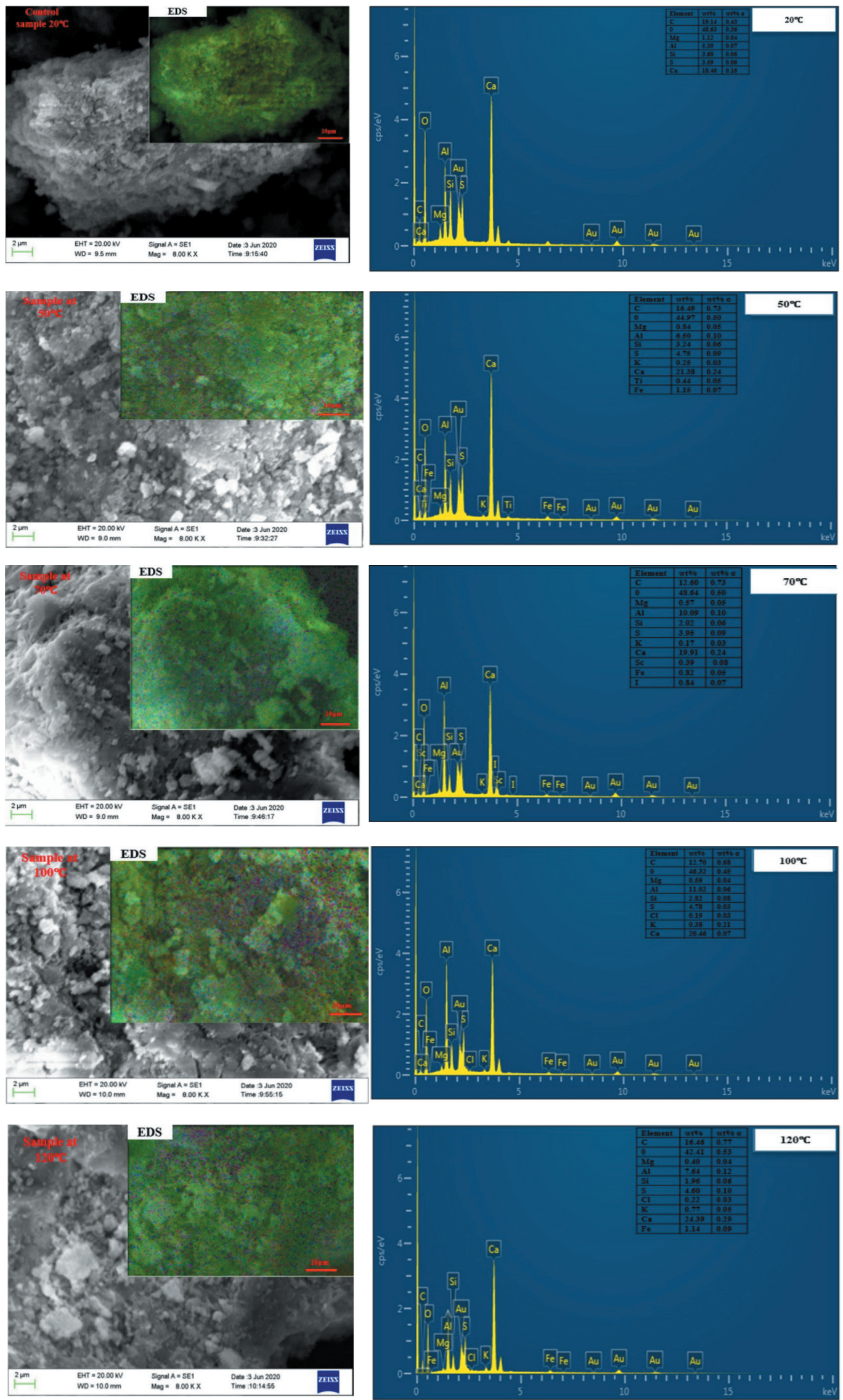

Fig. 21 SEM-EDS microstructure of the sulphoaluminate cement heated to $120^{\circ} \mathrm{C}$ 

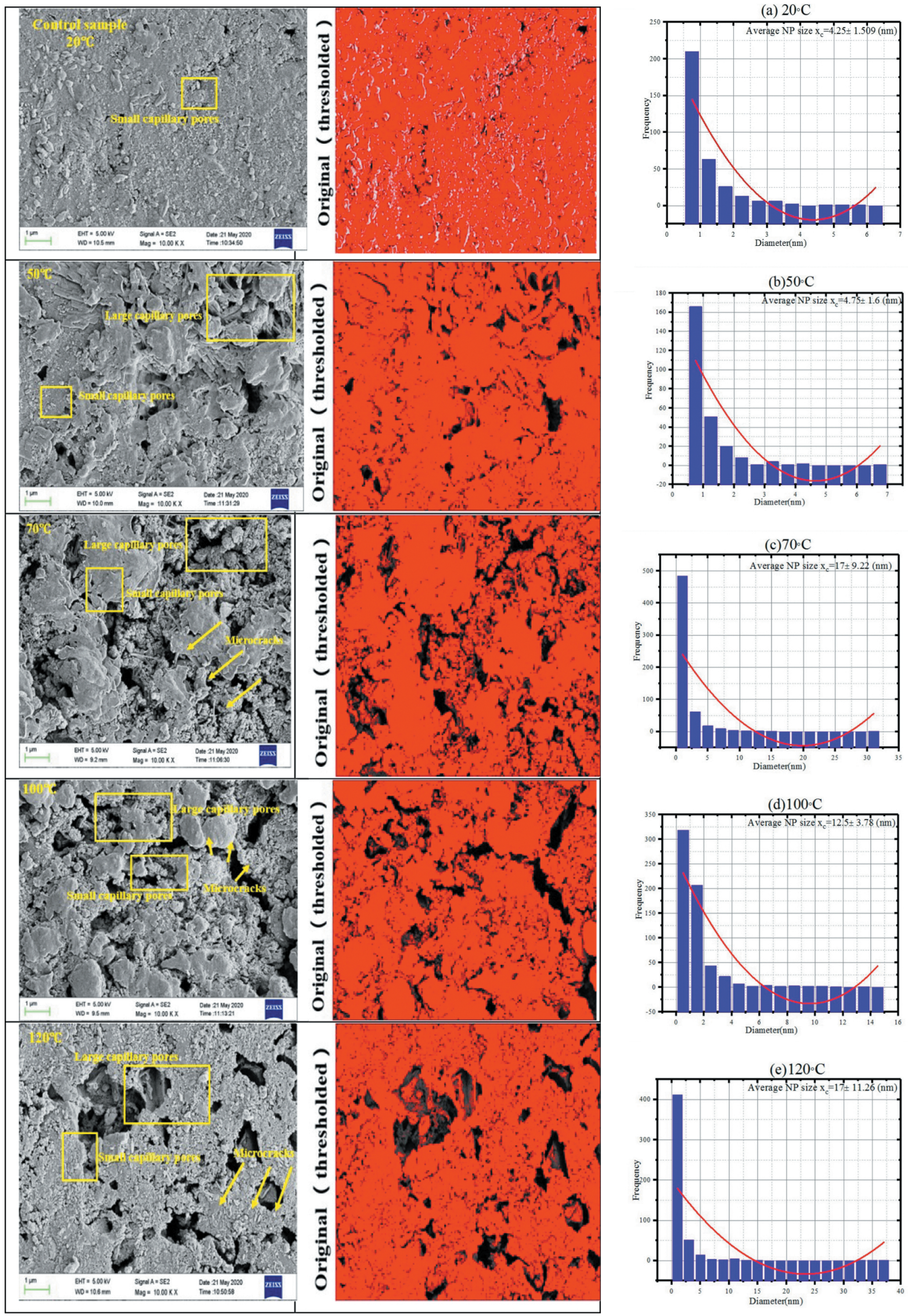

Fig. 22 MC micro-particles analyzed by ImageJ software: the SEM image of the different-cement paste 

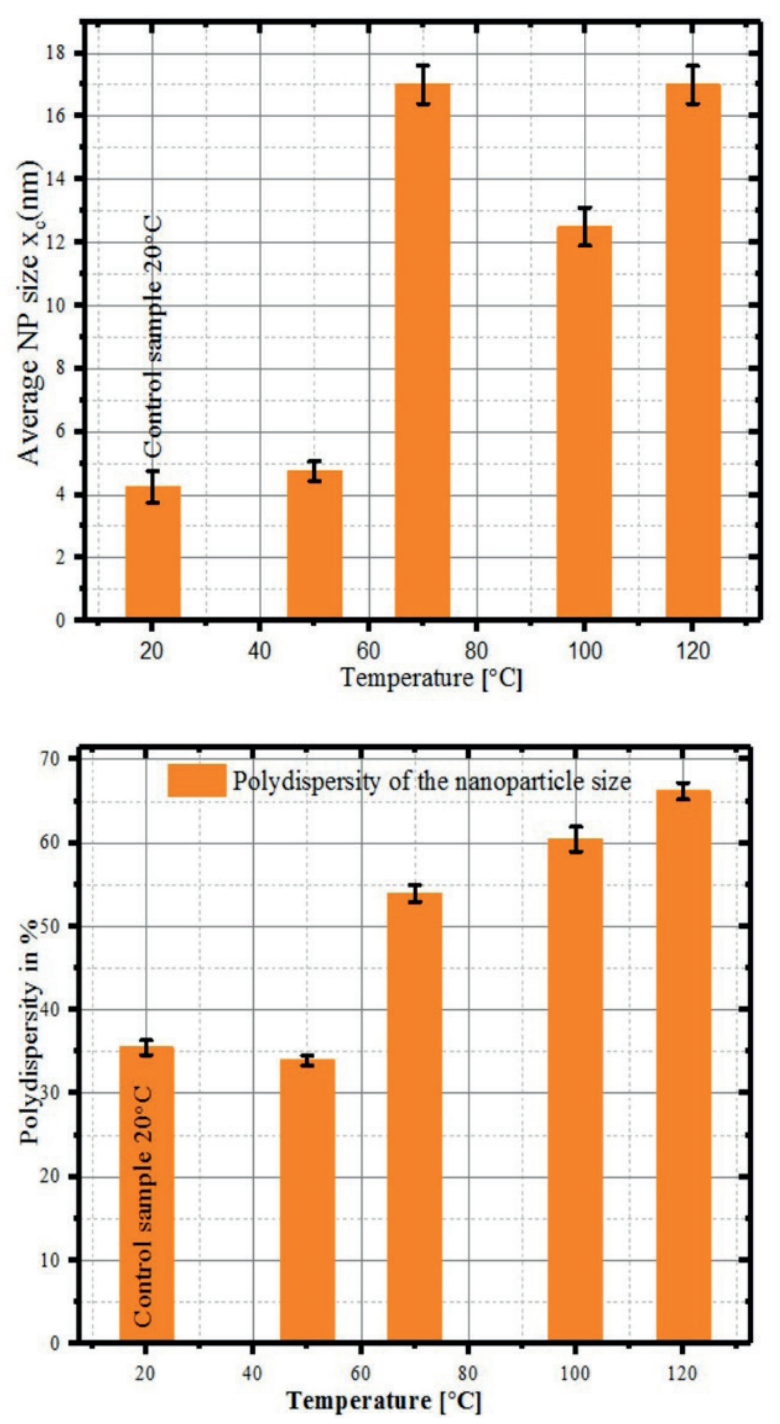

Fig. 23 Polydispersity of the size of nanoparticles observed at different temperatures

Fig. 24(b). Peaks could be found in the curve of the sample heated at $100^{\circ} \mathrm{C}$. But only one peak could be found at other temperatures in Fig. 24(b). This may be caused by the enlargement of gel pores due to dehydration. Table 7 shows the summary of the MIP testing.

The value of tortuosity $(\tau)$ plotted separately for each sample shows two trend curves; the tortuosity decreases with increasing temperature and then increases. Unlike $\varepsilon, \tau$ values show a definite trend; a sharp increase is noted at $70^{\circ} \mathrm{C}$. The sharp reduction value implies a tortuous flow-path (Fig. 25).

The ratio $\varepsilon / \tau$ is a characteristic material constant [38]. With the same design composition, each R-SAC paste sample, as a different porous system as the temperature increases, is expected to have its own constant $\varepsilon / \tau$ ratio. Table 8 shows the average ratio for each sample; $\varepsilon / \tau$ seems
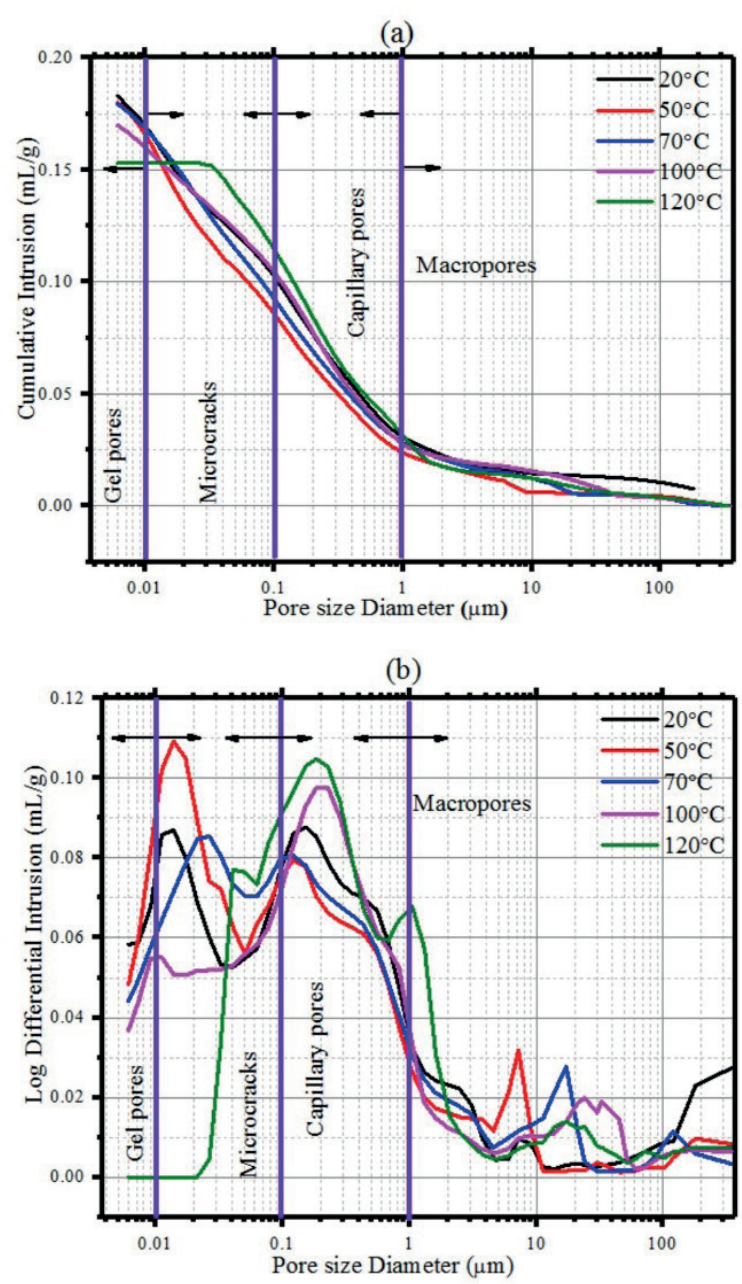

Fig. 24 MIP results of the R-SAC paste samples

Table 7 Summary of the MIP testing

\begin{tabular}{|c|c|c|c|c|c|}
\hline \multirow{2}{*}{ Temperature } & \multicolumn{5}{|c|}{ R-SAC } \\
\hline & $20^{\circ} \mathrm{C}$ & $50^{\circ} \mathrm{C}$ & $70^{\circ} \mathrm{C}$ & $100^{\circ} \mathrm{C}$ & $120^{\circ} \mathrm{C}$ \\
\hline $\begin{array}{l}\text { Total intrusion volume } \\
{[\mathrm{ml} / \mathrm{g}]}\end{array}$ & 0.15 & 0.16 & 0.17 & 0.18 & 0.18 \\
\hline Total pore area $\left[\mathrm{m}^{2} / \mathrm{g}\right]$ & 4.29 & 14.81 & 18.49 & 19.54 & 22.42 \\
\hline $\begin{array}{l}\text { Median pore diameter } \\
\text { (volume) }[\mu \mathrm{m}]\end{array}$ & 0.23 & 0.16 & 0.10 & 0.13 & 0.08 \\
\hline $\begin{array}{l}\text { Median pore diameter } \\
\text { (area) }[\mu \mathrm{m}]\end{array}$ & 0.06 & 0.01 & 0.01 & 0.01 & 0.01 \\
\hline $\begin{array}{l}\text { Average pore diameter } \\
(4 \mathrm{~V} / \mathrm{A})[\mu \mathrm{m}]\end{array}$ & 0.14 & 0.04 & 0.038 & 0.037 & 0.032 \\
\hline
\end{tabular}

to vary marginally across the range of temperature. The volumetric stability of the R-SACC is directly tied to the relative amount of AFt in the dehydration process, which is controlled by the chemistry of the R-SAC. When the temperature exceeded $70^{\circ} \mathrm{C}$, the R-SACC properties decreased steadily. As the temperature increased from $50^{\circ}$ to $120^{\circ} \mathrm{C}$, the trend of linear expansion of R-SACC and R-SAC was generally the same, showing expansion 

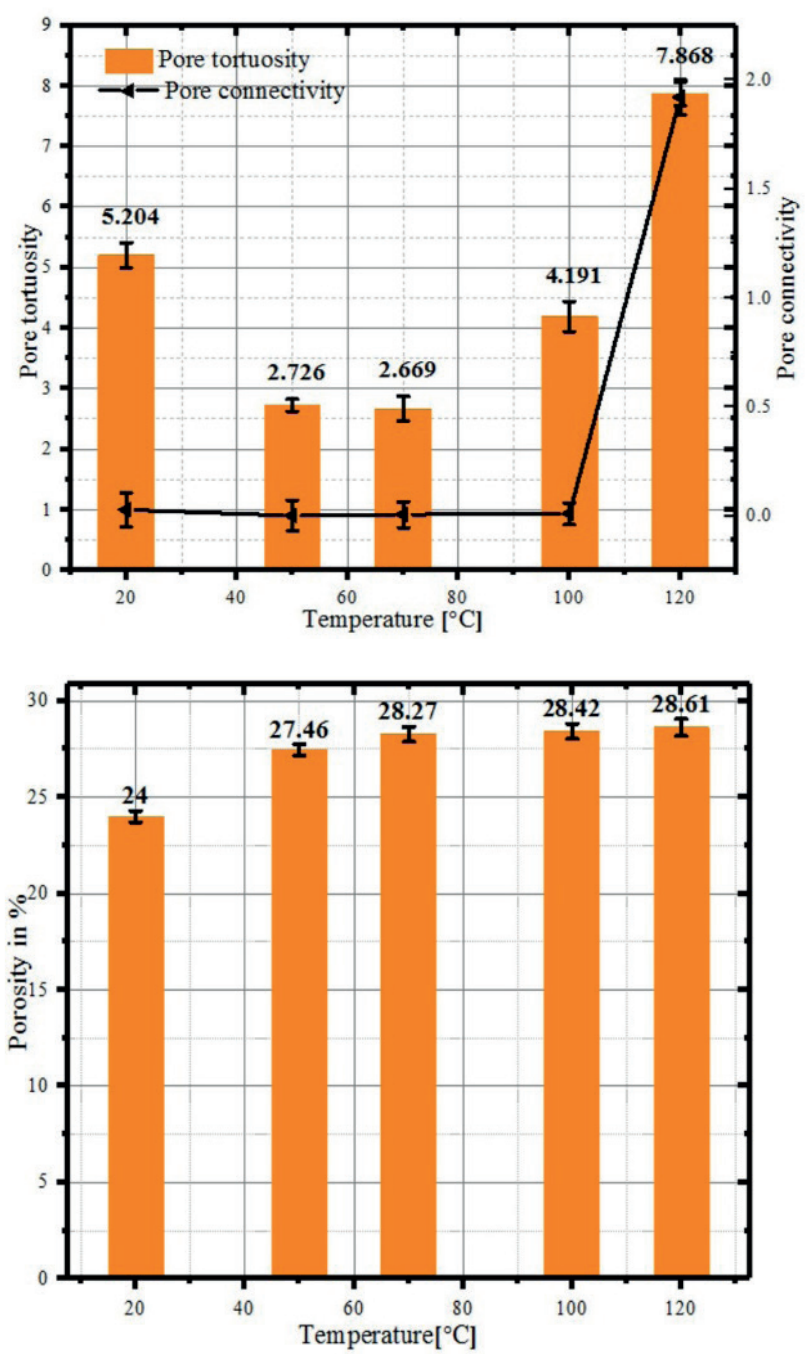

Fig. 25 Porosity, pore connectivity and diffusion tortuosity of the R-SAC pastes at different temperatures

Table 8 Values of the $\varepsilon / T$ ratio

\begin{tabular}{lccccc}
\hline Sample & $\begin{array}{c}\text { W/cm } \\
\text { ratio } \\
\text { (by wt.) }\end{array}$ & $\begin{array}{c}\text { Cement } \\
\text { content } \\
\mathrm{Kg} / \mathrm{m}^{3}\end{array}$ & $\begin{array}{c}\text { Porosity, } \varepsilon \text { (in } \\
\text { percentage) }\end{array}$ & $\begin{array}{c}\text { Tortuosity, } \\
\tau\end{array}$ & $\begin{array}{c}\varepsilon / \tau \\
\text { ratio }\end{array}$ \\
\hline $20^{\circ} \mathrm{C}$ & 0.4 & 540 & 24 & 520 & 4.61 \\
$50^{\circ} \mathrm{C}$ & 0.4 & 540 & 27.49 & 2.72 & 10.07 \\
$70^{\circ} \mathrm{C}$ & 0.4 & 540 & 28.27 & 2.69 & 10.50 \\
$100^{\circ} \mathrm{C}$ & 0.4 & 540 & 28.42 & 4.19 & 6.78 \\
$120^{\circ} \mathrm{C}$ & 0.4 & 540 & 28.61 & 8.86 & 3.22 \\
\hline
\end{tabular}

first and then contraction, but the expansion and contraction values of the R-SAC were much larger than those of the R-SACC. The main reason is that the expansion of R-SACC is affected by the dual effects of aggregate and R-SAC paste. The expansion of the aggregate limits the expansion or contraction of the R-SAC paste. Furthermore, during the heating of the R-SAC cement paste, free water, hydrated sulphoaluminate structured water and partially hydrated ettringite structured water were released starting at about $50^{\circ} \mathrm{C}$, and mainly around $70^{\circ}$ to $120^{\circ} \mathrm{C}$. The release of ettringite structured water produces, at around $100^{\circ}$ to $120^{\circ} \mathrm{C}$, mainly $\mathrm{C}_{3} \mathrm{~A} \cdot \mathrm{CaSO}_{4} \cdot 12 \mathrm{H}_{2} \mathrm{O}(\mathrm{AFm})$ dehydration. The use of colorimetry analysis and rebound hammer testing as a quick determination of thermally induced degradation (deterioration) of R-SACC, as described in this work, could be of great value to engineers responsible for monitoring the safety of structures made with R-SAC. We have shown that this method is effective, because the color intensity and the hammer number both evidence the reduction of strength, as shown in Table 9. The NDT rebound hammer performed and colorimetry concluded of a necessity reparation when the structure has been extended exposed to heat at the temperature between $50^{\circ} \mathrm{C}$ to $100^{\circ} \mathrm{C}$ and diagnose of the non-serviceability of the sample been extendedly exposure to $120^{\circ} \mathrm{C}$. Thus, in practice any R-SACC or R-SAC that has turned a yellowish tapa in color could be regarded as probably having deteriorated. Table 10 proposes a threshold table to predict the mechanical properties of the R-SACC after extended exposure to temperatures of up to $120^{\circ} \mathrm{C}$.

Temperatures of $70^{\circ}, 100^{\circ}$, and $120^{\circ} \mathrm{C}$ were found to have a significant impact not just on the chemical properties of the R-SAC but also on the stability of the structure.

Table 9 Correlation between colorimetry, the rebound hammer and strength

\begin{tabular}{lccccc}
\hline \multirow{2}{*}{ R-SACC Property } & \multicolumn{5}{c}{ Temperature $\left({ }^{\circ} \mathrm{C}\right)$} \\
& 20 control & 50 & 70 & 100 & 120 \\
\hline $\begin{array}{l}\text { Strength (compressive } \\
\text { strength) } \mathrm{MPa}\end{array}$ & 51.3 & 48.75 & 42.2 & 40.9 & 36.9 \\
RHN & 41 & 33 & 27 & 25 & 15 \\
\hline
\end{tabular}

Table 10 Threshold proposed to predict the mechanical properties of the R-SACC after heating to temperatures up to $120^{\circ} \mathrm{C}$

\begin{tabular}{|c|c|c|c|c|c|}
\hline \multirow[t]{2}{*}{ Step } & & \multicolumn{2}{|c|}{$\begin{array}{c}\text { Lower confidence } \\
\text { limit } \\
(2.5 \%)\end{array}$} & \multicolumn{2}{|c|}{$\begin{array}{c}\text { Upper confidence } \\
\text { limit } \\
(97.5 \%)\end{array}$} \\
\hline & & & nperature & & Temperature \\
\hline 1 & $\begin{array}{l}\text { Compressive } \\
\text { strength } \\
(\mathrm{MPa})\end{array}$ & 48.75 & $50^{\circ} \mathrm{C}$ & 51.3 & $20^{\circ} \mathrm{C}$ \\
\hline 2 & $\begin{array}{l}\text { Flexural } \\
\text { strength } \\
(\mathrm{MPa})\end{array}$ & 9.18 & $50^{\circ} \mathrm{C}$ & 9.93 & $20^{\circ} \mathrm{C}$ \\
\hline 3 & $\begin{array}{l}\text { Tensile } \\
\text { strength } \\
(\mathrm{MPa})\end{array}$ & $\begin{array}{c}1.69 \times \\
10^{-3}\end{array}$ & $50^{\circ} \mathrm{C}$ & $\begin{array}{c}2.5 \times \\
10^{-3}\end{array}$ & $20^{\circ} \mathrm{C}$ \\
\hline \multirow[t]{2}{*}{4} & Porosity (\%) & 27.46 & $50^{\circ} \mathrm{C}$ & \multirow[t]{2}{*}{24} & \multirow[t]{2}{*}{$20^{\circ} \mathrm{C}$} \\
\hline & & 70,1 &, $120^{\circ} \mathrm{C}$ & & \\
\hline
\end{tabular}




\section{Conclusions}

This study has focused on the weakening of R-SACC and $\mathrm{R}-\mathrm{SAC}$ in the zone of persistence of ettringite and on the zone of decomposition. The key conclusions are summarized below.

1. The RHN and colorimetry could serve as two quick predictive tests for monitoring R-SACC structures, since after extended heat exposure, both methods detected weakening in the properties of R-SACC and R-SAC paste. The RHN has demonstrated the non-serviceability of the specimens above $50^{\circ} \mathrm{C}$ by characterizing the R-SACC as only fair.

2. The chemico-physico-mechanical model of thermally induced degradation developed in this study shows that the acceptable mechanical properties were retained up to $50^{\circ} \mathrm{C}$, but above $50^{\circ} \mathrm{C}$, the strength dropped sharply. As the amount of ettringite decreased, the mechanical properties of the R-SACC and R-SAC pastes also decreased. The impact of the dehydration of the ettringite with increased temperatures was highlighted. Ettringite seemed to have the ability to compensate for dry shrinkage or to increase the expansion of R-SAC paste to a certain extent. XRD and TG-DSC results revealed that the ettringite promoted the dehydration of R-SAC paste.

3. The compressive strength decreased along with mass loss of the ettringite from $65.15 \%$ at $20^{\circ} \mathrm{C}$ to $5 \%$ at $104^{\circ} \mathrm{C}$ (TGA figure), while a shape decrease was observed at $120^{\circ} \mathrm{C}$ when ettringite content was above $0 \%$. The compressive strength reached its minimum value (36.9 $\mathrm{MPa})$ at an ettringite dosage of $0 \%$. The extent of the phenomenon is significantly bearable by the R-SACC at up to $50^{\circ} \mathrm{C}$.

\section{References}

[1] ACI "ACI 216.1-07/TMS-0212-07 Code Requirements for Determining Fire Resistance of Concrete and Masonry Construction Assemblies", American Concrete Institute, Farmington Hills, MI, USA, 2007.

[2] ACI "ACI-318-08 Building Code Requirements for Structural Concrete and Commentary", American Concrete Institute, Farmington Hills, MI, USA, 2008.

[3] Shi, C., Jiménez, F., Palomo, A. "New cement for the 21st century: The pursuit of an alternative to Portland cement", Cement and Concrete Research, 41, pp. 750-763, 2011. https://doi.org/10.1016/j.cemconres.2011.03.016

[4] Zhang, G., He, R., Lu, X., Wang, P. "Early hydration of calcium sulphoaluminate cement in the presence of hydroxyethyl methyl cellulose", Journal of Thermal Analysis and Calorimetry, 134, pp. 1429-1438, 2018.

https://doi.org/10.1007/s10973-018-7252-5
Above this temperature, the mismatch of thermal deformations between the R-SAC and aggregates, which expand and then undergo shrinkage, prevails and results in the development of cracks. Important cracking continues, thus altering the R-SACC mechanical properties.

4. Although there were few changes in the total porosity of R-SAC pastes with ettringite crystals, ettringite could significantly improve the pore structure by transforming large pores into small pores. R-SAC pastes after the dehydration of the ettringite showed a denser microstructure than control samples. In SEM graphs, R-SACC showed a quite high degree of porosity between $50^{\circ}$ and $70^{\circ} \mathrm{C}$. Temperatures of $70^{\circ}, 100^{\circ}$, and $120^{\circ} \mathrm{C}$ were found to have a significant impact not just on the chemical properties of the R-SAC but also on the stability of the structure. All in all, the extensive exposure to heat at the chosen range of temperatures in this work was found to have an impact on the stability of the structure, because the matrix formation of ettringite was broken, the mass of the hydrated product decreased with heat exposure, and the interface between aggregate and paste in the R-SACC became loosely structured with cracks. Therefore, builders of power plant structures should pay more attention to assuring their durability when exposed to heat.

\section{Acknowledgement}

This work was supported by the National Natural Science Foundation of China (Nos.51761145023 and 51632003), the Taishan Scholars Program, and the Case-by-Case Project for Top Outstanding Talents of Jinan.

[5] Sahu, S., Majling, J. "Preparation of sulphoaluminate belite cement from fly ash", Cement and Concrete Research, 24(6), pp. 1065-1072, 1994.

https://doi.org/10.1016/0008-8846(94)90030-2

[6] Jeong, Y., Hargis, G. W., Kang, H., Chun, S.-C., Moon, J. "The effect of elevated curing temperatures on high Ye'elimite calcium sulphoaluminate cement mortars", Materials, 12(7), Article No. 1072, 2019. https://doi.org/10.3390/ma12071072

[7] Xin, D., Chai, X., Zhao, W. "Hybrid cement-assisted dewatering, solidification and stabilization of sewage sludge with high organic content", Journal of Material Cycles and Waste Management, 18, pp. 356-365, 2016.

https://doi.org/10.1007/s10163-014-0337-8

[8] Ye, Q., Wang, W., Zhang, Li, J., Chen, H. "Turning the phase structure and mechanical performance of magnesium oxychloride cements by curing temperature and $\mathrm{H}_{2} \mathrm{O} / \mathrm{MgCl}_{2}$ ratio", Construction and Building Materials, 179, pp. 413-419, 2018.

https://doi.org/10.1016/j.conbuildmat.2018.05.257 
[9] Caporale, A., Feo, L., Luciano, R. "Damage mechanics of cement concrete modeled as a four-phase composite", Composites Part B: Engineering, 65, pp. 124-130, 2014.

https://doi.org/10.1016/j.compositesb.2014.02.006

[10] Zhou, Q., Glasser, F. P. "Thermal stability and decomposition mechanisms of ettringite at $<120^{\circ} \mathrm{C}$ ", Cement and Concrete Research, 31(9), pp. 1333-1339, 2001. https://doi.org/10.1016/S0008-8846(01)00558-0

[11] Jimenez, A., Prieto, M. "Thermal Stability of ettringite exposed to atmosphere: implications for the uptake of harmful ions by cement", Environmental Science and Technology, 49, pp. 7957-7964, 2015. https://doi.org/10.1021/acs.est.5b00536

[12] Grusczscinski, E., Brown, P. W., Bothe, Jr., J. V. "The formation of ettringite at elevated temperature", Cement and Concrete Research, 23(4), pp. 981-987, 1993. https://doi.org/10.1016/0008-8846(93)90052-B

[13] Damidot, D., Glasser, F. P. "Thermodynamic investigation of the $\mathrm{CaO}-\mathrm{Al}_{2} \mathrm{O}_{3}-\mathrm{CaSO}_{4}-\mathrm{H}_{2} \mathrm{O}$ system at $50^{\circ} \mathrm{C}$ and $84^{\circ} \mathrm{C}$.", Cement and Concrete Research, 22, pp. 1179-1191, 1992. https://doi.org/10.1016/0008-8846(92)90047-Y

[14] Sanfelix, S. G., Zea-García, J. D., Londono-Zuluag, D., Santacruz, I., De la Torre, A. G., Kjøniksena, A.-L. "Hydration development and thermal performance of calcium sulphoaluminate cements containing microencapsulated phase change materials", Cement and Concrete Research, 132, Article No. 106039, 2020. https://doi.org/10.1016/j.cemconres.2020.106039

[15] Collier, N. C. "Transition and decomposition temperatures of cement Phases - a collection of thermal analysis data", Ceramics-Silikáty, 60(4), pp. 338-343, 2016. https://doi.org/10.13168/cs.2016.0050

[16] Nijland, J. G., Larbi, J. A. "8 - Microscopic examination of deteriorated concrete", Non-Destructive Evaluation of Reinforced Concrete Structures, 1, pp. 137-179, 2010. https://doi.org/10.1533/9781845699536.2.137

[17] Mirza, W. H., Al-Noury, S. I., Al-Bedawi, W. H. "Temperature effect on strength of mortars and concrete containing blended cements", Cement and Concrete Composites, 13(3), pp. 197-202, 1991. https://doi.org/10.1016/0958-9465(91)90020-I

[18] Kodur, V. "Properties of Concrete at Elevated Temperatures", International Scholarly Research Notices, 2014, Article ID 468510, 2014.

https://doi.org/10.1155/2014/468510

[19] Wang, H.-L., Dai, J.-G., Sun, X.-Y., Zhang, X.-L. "Characteristics of concrete cracks and their influence on chloride penetration", Construction and Building Materials, 107, pp. 216-225, 2016. https://doi.org/10.1016/j.conbuildmat.2016.01.002

[20] Zhang, W., Pi, Y., Kong, W., Zhang, Y., Wu, P., Zeng, W., Yang, F. "Influence of damage degree on the degradation of concrete under freezing-thawing cycles", Construction and Building Materials, 260, Article No. 119903, 2020. https://doi.org/10.1016/j.conbuildmat.2020.119903

[21] Wang, J., Basheer, P. A. M., Nanukuttan, S. V., Long, A. E., Bai, Y. "Influence of service loading and the resulting micro-cracks on chloride resistance of concrete", Construction and Building Materials, 108, pp. 56-66, 2016. https://doi.org/10.1016/j.conbuildmat.2016.01.005
[22] Arienti, M., Hwang, J., Pickett, L., Shekhawat, Y. "Thermallylimited bubble growth model for the relaxation time of superheated fuels", International Journal of Heat and Mass Transfer, 159, Article No. $120089,2020$. https://doi.org/10.1016/j.ijheatmasstransfer.2020.120089

[23] Berardi, U., Gallardo, A. A. "Properties of concretes enhanced with phase change materials for building applications", Energy and Buildings, 199, pp. 402-414, 2019. https://doi.org/10.1016/j.enbuild.2019.07.014

[24] Hou, S., Liu, F., Wang, S., Bian, H. "Coupled heat and moisture transfer in hollow concrete block wall filled with compressed straw bricks", Energy and Buildings, 135, pp. 84-87, 2017. https://doi.org/10.1016/j.enbuild.2016.11.026

[25] Liu, Y., Sun, F., Yu, K., Yang, Y. "Experimental and numerical research on development of synthetic heat storage form incorporating phase change materials to protect concrete in cold weather", Renewable Energy, 149, pp. 1424-1433, 2020. https://doi.org/10.1016/j.renene.2019.10.142

[26] Du, S., Zhang, Y., Sun, Q., Gong, W., Geng, J., Zhang, K. "Experimental study on color change and compression strength of concrete tunnel lining in a fire", Tunnelling and Underground Space Technology, 71, pp. 106-114, 2018. https://doi.org/10.1016/j.tust.2017.08.025

[27] Georgali, B., Tsakiridis, P. E. "Microstructure of fire-damaged concrete. A case study", Cement and Concrete Composites, 27(2), pp. 255-259, 2005. https://doi.org/10.1016/j.cemconcomp.2004.02.022

[28] Ling, H., Qian, C. "Effects of self-healing cracks in bacterial concrete on the transmission of chloride during electromigration", Construction and Building Materials, 144, pp. 406-411, 2017. https://doi.org/10.1016/j.conbuildmat.2017.02.160

[29] Short, N. R., Purkiss, J. A., Guise, S. E. "Assessment of fire damaged concrete using colour image analysis", Construction and Building Materials, 15(1), pp. 9-15, 2001 https://doi.org/10.1016/S0950-0618(00)00065-9

[30] Tchekwagep, J. J. K., Wang, S., Mukhopadhyay, A. K., Huang, S., Cheng, X. "Compressive strength of rapid sulfoaluminate cement concrete exposed to elevated temperatures", Ceramics-Silikáty, 64(3), pp. 299-309, 2020. https://doi.org/10.13168/cs.2020.0019

[31] Colombo, M., Felicetti, R. "New NDT technique for assessment of fire- damaged concrete structures", Fire Safety Journal, 42(6-7), pp. 461-472, 2007. https://doi.org/10.1016/j.firesaf.2006.09.002

[32] Zhao, M., Nie, Z., Wang, K., Liu, P., Zhang, X. "Nonlinear ultrasonic test of concrete cubes with induced crack", Ultrasonics, 97, pp. 1-10, 2019. https://doi.org/10.1016/j.ultras.2019.04.002

[33] Tatarinov, A., Rumjancevs, A., Mironovs, V. "Assessment of cracks in pre-stressed concrete railway sleepers by ultrasonic testing", Procedia Computer Science, 149, pp. 324-330, 2019. https://doi.org/10.1016/j.procs.2019.01.143

[34] Hager, I. "Behaviour of cement concrete at high temperature", Bulletin of the Polish Academy of Sciences, Technical Sciences, 61(1), pp. 145-154, 2013. https://doi.org/10.2478/bpasts-2013-0013 
[35] Niu, X.-J., Li, Q.-B., Liu, W.-J., Hu, Y. "Effects of ambient temperature, relative humidity and wind speed on interlayer properties of dam concrete", Construction and Building Materials, 260, Article No. 119791, 2020.

https://doi.org/10.1016/j.conbuildmat.2020.119791

[36] $\mathrm{Xu}, \mathrm{T} ., \mathrm{Li}, \mathrm{J}$. "Assessing the spatial variability of the concrete by the rebound hammer test and compression test of drilled cores", Construction and Building Materials, 188, pp. 820-832, 2018. https://doi.org/10.1016/j.conbuildmat.2018.08.138
[37] Thomas, C., Setién, J., Polanco, J. A., de Brito, J., Fiol, F. "Microand macro-porosity of dry- and saturated-state recycled aggregate concrete", Journal of Cleaner Production, 211, pp. 932-940, 2019. https://doi.org/10.1016/j.jclepro.2018.11.243

[38] Akhavan, A., Shafaatian, S.-M.-H., Rajabipour, F. "Quantifying the effects of crack width, tortuosity, and roughness on water permeability of cracked mortars", Cement and Concrete Research, 42(2), pp. 313-320, 2012.

https://doi.org/10.1016/j.cemconres.2011.10.002 